\title{
The Chukchi Slope Current ${ }^{2}$
}

\author{
W. Bryce Corlett ${ }^{a, b, *}$, Robert S. Pickart ${ }^{b}$ \\ ${ }^{a}$ MIT-WHOI Joint Program in Oceanography/Applied Ocean Science and Engineering, Cambridge, MA \\ 02139, USA. \\ ${ }^{b}$ Woods Hole Oceanographic Institution, Woods Hole, MA 02543, USA.
}

\begin{abstract}
Using a collection of 46 shipboard hydrographic/velocity transects occupied across the shelfbreak and slope of the Chukchi Sea between 2002-2014, we have quantified the existence of a current transporting Pacific-origin water westward over the upper continental slope. It has been named the Chukchi slope current, which is believed to emanate from Barrow Canyon. The current is surface-intensified, order $50 \mathrm{~km}$ wide, and advects both summer and winter waters. It is not trapped to a particular isobath, but instead is reminiscent of a free jet. There is no significant variation in Pacific water transport with distance from Barrow Canyon. A potential vorticity analysis suggests that the flow is baroclinically unstable, consistent with the notion that it meanders. The current is present during all synoptic wind conditions, but increases in strength from summer to fall presumably due to the seasonal enhancement of the easterly winds in the region. Its transport increased over the 12-year period of data coverage, also likely in response to wind forcing. In the mean, the slope current transports $0.50 \pm 0.07 \mathrm{~Sv}$ of Pacific water. This estimate allows us to construct a balanced mass budget of the Chukchi shelf inflows and outflows. Our study also confirms the existence of an eastward-flowing Chukchi shelfbreak jet transporting $0.10 \pm 0.03 \mathrm{~Sv}$ of Pacific water towards Barrow Canyon.
\end{abstract}

Keywords: Arctic Ocean, Chukchi Sea, Shelfbreak, Mass Budget

\footnotetext{
This document should be cited as: Corlett, W.B., Pickart, R.S., 2017. The Chukchi slope current. Progress in Oceanography 153, 50-65, doi:10.1016/j.pocean.2017.04.005.

*Corresponding author

Email address: bcorlett@whoi.edu (W. Bryce Corlett)
} 


\section{Introduction}

The means by which Pacific water crosses the Chukchi Sea, and the locations where the water exits the shelf into the interior Arctic Ocean, directly impacts various aspects of the Arctic ecosystem. The three main pathways of Pacific water on the shelf are the western branch into Herald Canyon, the Central Channel branch which flows northward between Herald and Hanna shoals, and the coastal pathway (known as the Alaskan coastal current in summer and fall, Fig. 1). During winter and spring, cold Pacific water flows through Bering Strait into the Chukchi Sea (Woodgate et al., 2005). This water is high in nutrients (Lowry et al., 2015), and consequently helps spur primary production on the shelf (Hill et al., 2005; Arrigo et al., 2014). In late spring and summer, warmer and fresher Pacific waters enter the Chukchi Sea, which are believed to play a significant role in both melting and delaying the formation of pack-ice both on the shelf (e.g. Weingartner et al., 2005) and in the basin (Steele et al., 2010; Woodgate et al., 2012; Brugler et al., 2014). The Pacific water transported across the shelf is also believed to contribute significantly to the reservoir of freshwater offshore in the Beaufort Gyre (e.g. Pickart et al., 2013b).

The coldest type of Pacific water is known as newly-ventilated winter water (WW), which is near the freezing point. This originates from the northern Bering Sea (e.g. Muench et al., 1988), but can also be formed, or further transformed, locally on the Chukchi shelf in polynyas and leads (e.g. Weingartner et al., 1998; Itoh et al., 2012; Pickart et al., 2016; Pacini et al., submitted). As the season progresses, the temperature of this water moderates via solar heating and/or mixing with warmer ambient waters, at which point it is referred to as remnant winter water (RWW). (In the case of extreme warming, the WW can be converted to a weakly stratified summer water mass, Gong and Pickart, 2016). During summer and early fall, the Chukchi Sea contains two different types of warm Pacific water masses. The first is Alaskan coastal water (ACW) which stems largely from fluvial runoff in the Gulf of Alaska. The second is a combination of Anadyr water and central Bering shelf water, which

mix north of Bering Strait (Coachman et al., 1975) to form a water mass known as Bering summer water (BSW). 


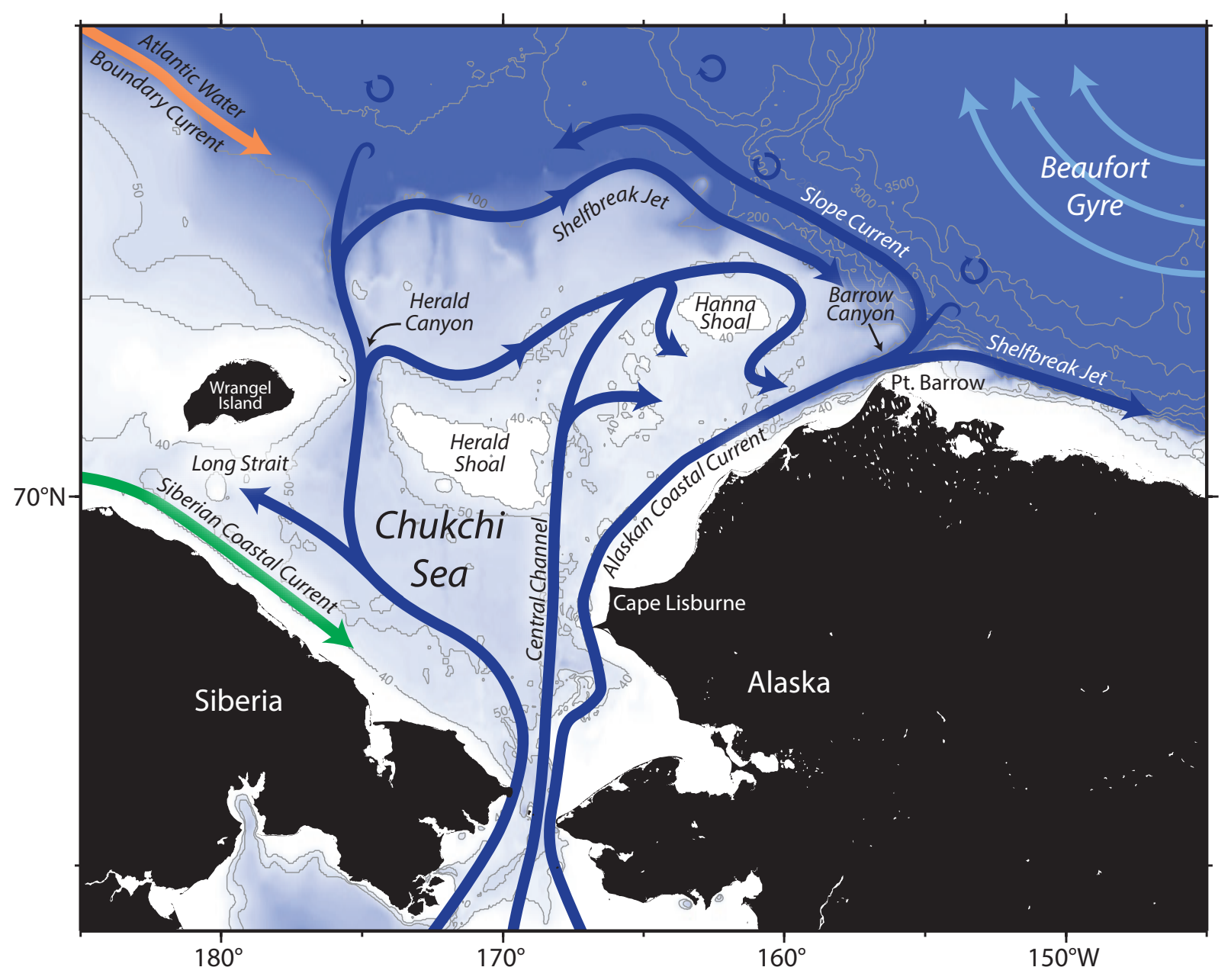

Figure 1: Revised schematic of the circulation of the Chukchi Sea and western Beaufort Sea from Brugler et al. (2014), including an extended Chukchi shelfbreak jet and the newly-described Chukchi slope current based on the results of this study. 
Recent studies have revised our understanding of the circulation of Pacific-origin water on the Chukchi shelf, including the partitioning of transport between the different flow pathways. While the notion of three main branches remains intact, it is now believed that, as the Pacific water progresses across the shelf, it divides into a number of smaller branches or filaments on the northeast part of the shelf (Pickart et al., 2016). Among other things, this impacts the timing of the advection of the high-nutrient WW across the shelf, which in turn has ramifications for the primary production (Lowry et al., 2015). With regard to transport, the yearly averaged volume flux in each the three main flow branches is thought to be comparable (Woodgate et al., 2005). However, recent data suggest that, at least during the summer months, much of the Pacific water entering Bering Strait drains into Barrow Canyon in the northeast part of the shelf (Itoh et al., 2013, Gong and Pickart, 2016; Pickart et al., 2016).

Presently, the mechanisms by which Pacific water exits the Chukchi shelf into the Canada basin - and the geographical locations where this occurs - are not fully understood. It is known that some portion of the outflowing Pacific water ends up as a shelfbreak jet that, in the mean, flows eastward along the edge of the Beaufort Sea Nikolopoulos et al., 2009). While the configuration of this jet changes seasonally (surface-intensified during late-summer/early-fall, bottom-intensified over the remainder of the year), the current is a year-round feature. There is also evidence of a shelfbreak jet along the edge of the Chukchi Sea, that, in the absence of wind forcing, flows to the east (Pickart et al., 2005; Mathis et al., 2007; Llinás et al., 2009; Pickart et al., 2016). The source of this is believed to be the outflow from Herald Canyon (Pickart et al. 2010). However, the data are largely anecdotal, and there are no published estimates of the transport of this shelfbreak flow.

Notably, the volume transport of Pacific water in the Beaufort shelfbreak jet is only a small fraction of what enters the Chukchi Sea through Bering Strait. Using data from seven moorings deployed across the current from 2002-3, Nikolopoulos et al. (2009) calculated the mean volume flux of Pacific water to be $0.13 \pm 0.08 \mathrm{~Sv}$, which is only about $15 \%$ of the long-term transport through Bering Strait (0.83 Sv, Roach et al., 1995). Furthermore, while the northward volume flux through Bering Strait has increased in recent years to just 
over $1 \mathrm{~Sv}$ (Woodgate et al. 2012), the eastward transport of Pacific water in the Beaufort shelfbreak jet has decreased to 0.021-0.041 Sv (Brugler et al., 2014). This implies that the jet now only accounts for less than $5 \%$ of the Pacific water that enters the Chukchi Sea. (The summertime transport of the Beaufort shelfbreak jet increases to approximately 0.25 Sv (Brugler et al. 2014), still far less than the transport through Bering Strait.)

This begs the question, where and how does the bulk of the Pacific water exit the Chukchi Shelf? As noted above, Woodgate et al. (2005) argued that each of the three main branches transports a similar amount of Pacific water. However, a significant portion of the water in the western branch is diverted to the east just north of Herald Shoal (Pickart et al., 2010), progressing along the northern Chukchi shelf and joining the central branch (Spall, 2007, Pickart et al., 2016, see Fig. 1). This combined central/western branch is then believed to flow into Barrow Canyon, adding to the puzzle regarding the small transport of the Beaufort shelfbreak jet. Brugler et al. (2014) attributed the recent decrease in strength of the Beaufort shelfbreak jet to enhanced easterly winds. This is consistent with the larger number of wind-driven upwelling events over the last decade noted by Pickart et al. (2013a), during which the flow of the jet is reversed to the west (Schulze and Pickart, 2012). Brugler et al. (2014) presented data from a shipboard section occupied across the Chukchi slope just west of Barrow Canyon, which, together with a series of satellite images, revealed that the outflow from the canyon veered westward during such an event. This may provide a clue as to the fate of the Pacific water exiting the canyon and hence the "missing" transport in the Beaufort shelfbreak jet, but it should be remembered that this was only a synoptic occurrence.

Unlike the Beaufort Sea, where the shelfbreak jet is robustly documented using both mooring and shipboard data, the circulation along the Chukchi shelfbreak and slope has yet to be quantified. In light of the unaccounted transport leaving Barrow Canyon, and the observation of a jet of water veering to the west out of the canyon during a wind event, this motivates a study of the flow along the outer edge of the Chukchi Sea. Here we use a collection of historical shipboard sections occupied across the Chukchi shelfbreak/slope to investigate the circulation during the warm months of the year. The data reveal the exis- 
tence of a heretofore unquantified current over the Chukchi slope that advects a significant amount of Pacific-origin water westward. The data also robustly document the presence of an eastward-flowing shelfbreak jet transporting a small amount of Pacific water toward Barrow Canyon. The paper is organized as follows. We start with a presentation of the shipboard data and an explanation of the technique used to create a mean section. We then describe the mean characteristics of the Chukchi slope current and shelfbreak jet, including the water masses they advect. This is followed by an investigation of the seasonal and interannual variation of the slope current. Next we explore the nature of the slope current and some aspects of its dynamics. Finally, we discuss the ramifications of these new components of the circulation in light of the mass budget of the Chukchi shelf.

\section{Data}

\subsection{Shipboard hydrographic and velocity data}

We have compiled all publicly-available shipboard sections occupied across the Chukchi shelfbreak/slope with the criteria that (1) they have high spatial resolution (typical station spacing of approximately $10 \mathrm{~km}$ ), and (2) direct velocity measurements were made in addition to the hydrographic measurements. This resulted in 46 sections carried out during the period 2002-14 (Table 1), spanning geographically from west of Barrow Canyon to $168^{\circ} \mathrm{W}$ (Fig. 22). All but two of the cruises were done on the USCGC Healy. The exceptions were the July-Aug 2002 cruise on the USCGC Polar Star and the July-Aug 2003 cruise on the R/V Nathaniel B. Palmer. In each case a Sea-Bird 911+ conductivity-temperature-depth (CTD) instrument was used, with dual T/C sensors that were calibrated pre- and postcruise. Most of the velocity measurements were made with a hull-mounted acoustic Doppler current profiler (ADCP), except the Polar Star cruise which used a lowered ADCP.

The data extend seasonally from May through October, although all of the May and June occupations occurred during 2002-4. Therefore, the seasonal analysis is restricted to the months of July through October. In addition, there were no sections occupied between 2005 and 2008, so for the interannual analysis we consider two time periods: 2002-4, which 


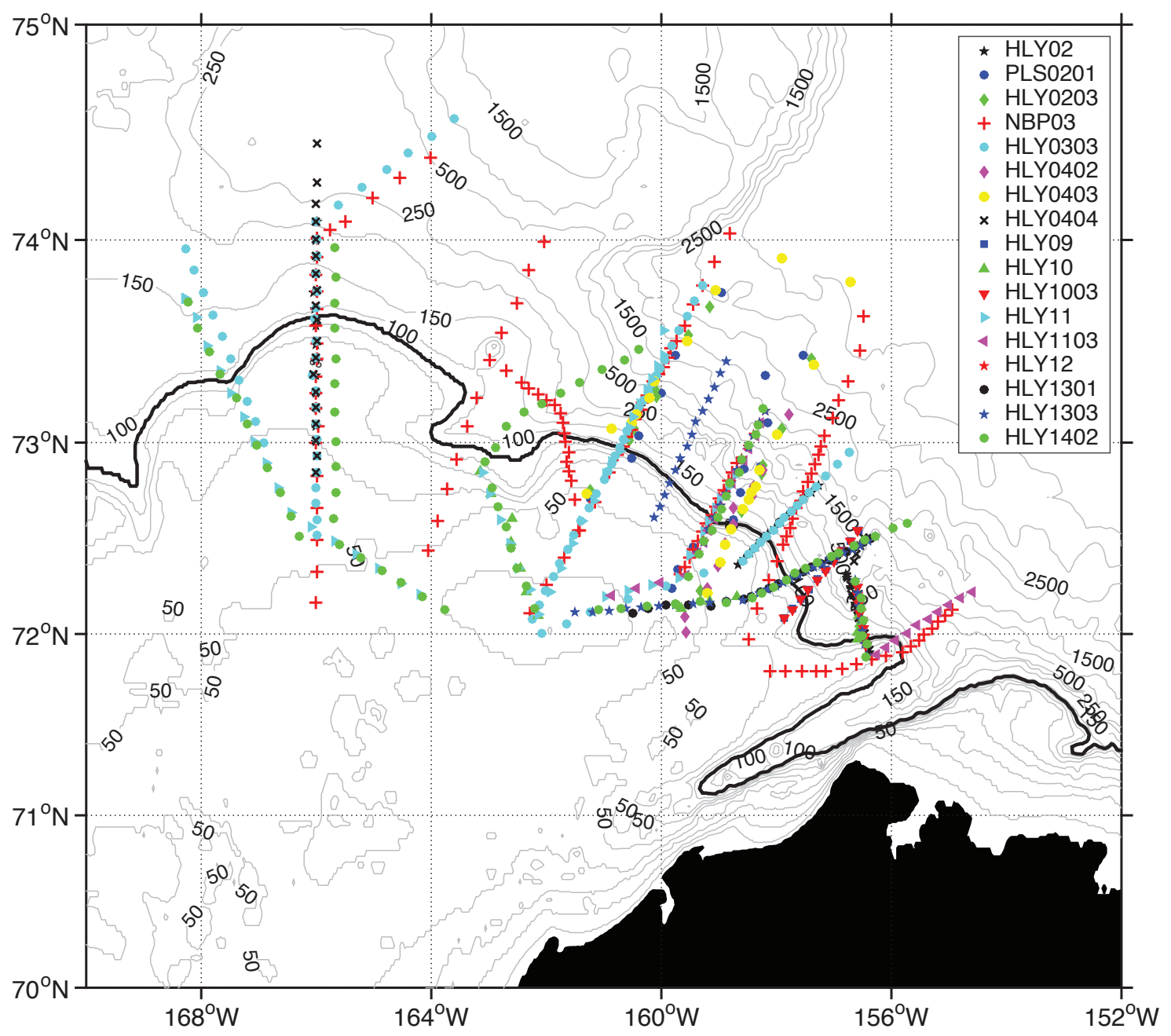

Figure 2: Locations of the 46 shipboard sections used in the study, color coded by cruise (see the legend and Table 1). The symbols denote the CTD stations comprising each section. The 90-m isobath is highlighted bold. 
is referred to as the early regime, and 2009-14, which is referred to as the recent regime. All of the cruises in the early time period were conducted as part of the Western Arctic ShelfBasin Interactions (SBI) program. To avoid confounding spatial and interannual trends, both the spatial and interannual analyses have been restricted to a region within $300 \mathrm{~km}$ of Barrow Canyon.

\subsection{Surface winds}

To assess the impact of winds on the hydrographic and velocity structure in our domain, we used the North American Regional Reanalysis (NARR) 10-m wind field (Mesinger et al. 2006), which has a spatial and temporal resolution of $32 \mathrm{~km}$ and 6 hours, respectively. The wind conditions for each shipboard transect were characterized by averaging over the 36 hours prior to the midpoint time of the section. We considered the along-shelfbreak component of the wind, where the orientation of the shelfbreak $\left(119.6^{\circ} \mathrm{T}\right)$ was determined using a linear regression of the $90 \mathrm{~m}$ isobath between $166^{\circ} \mathrm{W}$ and the mouth of Barrow Canyon. Along-shelfbreak winds are hereafter referred to as easterly (negative) and westerly (positive) winds.

\section{Methods}

\subsection{Gridding and Averaging}

Vertical sections of hydrographic variables (potential temperature, salinity, and potential density) were constructed for each transect using a Laplacian-spline interpolator. This was also done for the cross-transect component of the ADCP velocity. The gridded velocity was then used to reference the gridded sections of thermal wind shear to compute sections of absolute geostrophic velocity, where the matching was done at each grid point over the common depth range of the thermal wind shear and directly-measured velocity.

It is of interest to compute mean vertical sections of the various properties. In order to do this, it was necessary to construct an average cross-slope bottom profile and to locate each CTD station along this profile. As a first step, we followed the methodology of Pickart (2004) by constructing a Cartesian coordinate system aligned with the $90 \mathrm{~m}$ isobath over our 
Table 1: Hydrographic and velocity data sources, delineated between cruise (by row) and section (by semicolons). VMADCP $=$ vessel-mounted ADCP; LADCP $=$ lowered ADCP.

\begin{tabular}{|c|c|c|c|c|c|}
\hline Cruise & Ship & Year & Month & Dates & Velocity \\
\hline HLY02 & USCGC Healy & 2002 & May & $17-22 ; 23-30$ & VMADCP \\
\hline PLS0201 & USCGC Polar Star & 2002 & Jul./Aug. & $21-22 ; 4-6$ & LADCP \\
\hline HLY0203 & USCGC Healy & 2002 & Aug. & $6-12 ; 13-18$ & VMADCP \\
\hline NBP03 & R/V N.B. Palmer & 2003 & Jul./Aug. & $\begin{array}{l}23-26 ; \quad 27-31 ; \\
3-4 ; 5-7 ; 7-8 \\
8-9 ; 10-11\end{array}$ & VMADCP \\
\hline HLY0303 & USCGC Healy & 2003 & Sep./Oct. & $\begin{array}{l}16-17 ; \quad 17-19 \\
11-14 ; 15-16\end{array}$ & VMADCP \\
\hline HLY0402 & USCGC Healy & 2004 & May/Jun. & $24-4$ & VMADCP \\
\hline HLY0403 & USCGC Healy & 2004 & Aug. & $10-17 ; 18-24$ & VMADCP \\
\hline HLY0404 & USCGC Healy & 2004 & Sep. & $15-16 ; 17-19$ & VMADCP \\
\hline HLY09 & USCGC Healy & 2009 & Aug. & 6 & VMADCP \\
\hline HLY10 & USCGC Healy & 2010 & Jul. & $\begin{array}{l}11 ; 13-14 ; 14- \\
15\end{array}$ & VMADCP \\
\hline HLY1003 & USCGC Healy & 2010 & Sep. & $11 ; 12$ & VMADCP \\
\hline HLY11 & USCGC Healy & 2011 & Jul. & $\begin{array}{l}7-8 ; 9-10 ; 10- \\
12 ; 14-15\end{array}$ & VMADCP \\
\hline HLY1103 & USCGC Healy & 2011 & Oct. & $8-9 ; 22$ & VMADCP \\
\hline HLY12 & USCGC Healy & 2012 & Oct. & $9-11$ & VMADCP \\
\hline HLY1301 & USCGC Healy & 2013 & Aug. & $13-14$ & VMADCP \\
\hline HLY 1303 & USCGC Healy & 2013 & Oct. & $\begin{array}{l}10-11 ; 13 ; 13- \\
14 ; 15\end{array}$ & VMADCP \\
\hline HLY 1402 & USCGC Healy & 2014 & Jul. & $\begin{array}{l}10-11 ; 13 ; 13- \\
14 ; 20-22 ; 22- \\
23 ; 24-25\end{array}$ & VMADCP \\
\hline
\end{tabular}


domain of interest (the topography was smoothed first). Then a cross-slope bottom profile was created for each section (bottom depth versus cross-stream distance in the Cartesian frame). The value of bottom depth was the echosounder depth associated with the station (for those stations with no recorded echosounder value we used an interpolated value from ETOPO-2, which was less than $10 \%$ of the time).

After each of the bottom profiles was made, we aligned them at the shelfbreak, where the shelfbreak was defined as the location of the greatest change in bathymetric slope along the section. Then the mean bottom was computed at each cross-slope location $(x=0$ corresponds to the shelfbreak). Next, every station was assigned a cross-stream location along the mean profile according to its bottom depth. This resulted in some distortion in the station spacing for the sections. However, the largest distortions of the along-section distance between stations occurred at the inshore and offshore ends of the sections, and, overall, the majority of between-station spacings were changed by a factor less than three (most cases corresponded to reduced spacing). The mean vertical property sections were then computed using the Laplacian-spline interpolator, with a grid spacing of $3 \mathrm{~km}$ in $x$, and $5 \mathrm{~m}$ in depth $(z)$.

For completeness we tried two other techniques for computing the mean bottom profile: (1) aligning the sections at a given isobath $(90 \mathrm{~m})$, and $(2)$ doing the same except that the bottom depths along each section were computed using ETOPO-2 at the resolution of the digital product (i.e. to obtain higher cross-stream resolution of the bottom). Reassuringly, these other two techniques produced comparable results.

\subsection{Defining the currents}

As noted in the introduction, our collection of shipboard sections revealed the presence of a westward-flowing current over the Chukchi slope. Such a feature was observed in 37 of the 46 transects ( $80 \%$ of the occupations); all but two of the transects in which the feature did not occur are limited in their off-shelf extent (less than $30 \mathrm{~km}$ off-shelf). In order to quantify the characteristics of the current we needed to objectively define its width and vertical scale in each of the vertical sections (in addition to the mean section). We did this 
using the $5 \mathrm{~cm} / \mathrm{s}$ velocity anomaly contour, where the anomaly was relative to the mean velocity across the entire section (i.e. the full lateral and vertical extent of the section). We note that in some instances there was an additional region of enhanced westward flow at the offshore end of the section (discussed below). In the cases when the $5 \mathrm{~cm} / \mathrm{s}$ anomaly contour did not reach the surface on either side of the slope current, we used the locations where this contour reached its minimum depth to delineate the width of the current.

The location and dimensions of the shelfbreak jet were also defined by the $5 \mathrm{~cm} / \mathrm{sec}$ anomaly contour, but in this case the flow could be either eastward or westward. This feature was present in 30 of the 46 transects (65\% of the occupations; in the remaining occupations the flow near the shelfbreak was very weak). As an added constraint we limited the offshore extent of the jet to be within the vicinity of the shelfbreak to avoid the contamination of shelfbreak jet estimates by the slope current.

\subsection{Calculating fluxes}

Following Woodgate et al. (2010), we calculate heat fluxes relative to the freezing point of seawater in Bering Strait:

$$
\int\left(\rho\left(\theta-\theta_{0}\right) C_{p} U_{g}\right) \partial A
$$

where $\theta$ is the potential temperature, $C_{p}$ is the specific heat of seawater, $U_{g}$ is the absolute geostrophic velocity, and $\theta_{0}$ is the reference temperature $\left(-1.91^{\circ} \mathrm{C}\right)$. The integral is taken over the cross-sectional area of the section $(A)$.

Freshwater fluxes are determined relative to the mean Arctic salinity reported by Aagaard and Carmack (1989):

$$
\int\left(\left(1-\frac{S}{S_{0}}\right) U_{g}\right) \partial A
$$

where $S$ is the salinity and $S_{0}$ is the reference salinity (34.8).

Fluxes are calculated for both the Pacific water and Atlantic water. Following Nikolopoulos et al. (2009), we take the boundary between these two water masses to be the depth of maximum Ertel potential vorticity across the section. This corresponds to the base of the Pacific WW layer and is generally near $-1.3^{\circ} \mathrm{C}$ (see Nikolopoulos et al. (2009) for details). 


\section{Mean conditions}

\subsection{Structure}

Using the technique described in Section 3.1, we created mean vertical sections of hydrographic variables and velocity. Before presenting these, however, it is informative to quantify the different water masses observed on the Chukchi slope. This was done by constructing a volumetric temperature/salinity (T/S) diagram (Fig. 3) for all of the data seaward of the $90 \mathrm{~m}$ isobath. The four Pacific water masses described in the introduction are labeled in the figure. Our analysis also includes a fresher water mass that is composed of fluvial, precipitation, and ice melt contributions; this water mass is labelled "meltwater" to be consistent with the literature (e.g. Gong and Pickart, 2016; Lin et al., 2016). We note that these water mass boundaries are not precise and should be considered as guidelines, since the characteristics of the Pacific water change from year to year (e.g. Pisareva et al., 2015). Nonetheless the core $\mathrm{T} / \mathrm{S}$ values of the different water masses are robust and distinct.

By far, the most common type of Pacific water measured on the Chukchi slope, for the months of May to October, is RWW (46.2\%). This is true as well for the Beaufort slope (over the full seasonal cycle; Brugler et al., 2014). Although much less common, there were appreciable amounts of WW measured in the surveys (3.3\%). Regarding the two summer Pacific water masses, BSW was present to a moderate degree (5.2\%), while there was only a small amount of ACW (less than 1\%, although seasonally the amount was larger, see Section 5.1). The presence of these warm Pacific waters is addressed below. The final two water masses in Fig. 3 are the Atlantic water (AW) at depth (33.6\%) and meltwater (MW) in the surface layer $(11.6 \%)$.

Returning now to the mean vertical sections, the average potential temperature section (Fig. 4a) shows a warm surface layer, cold intermediate layer, and a warm deep layer below about $150 \mathrm{~m}$. The cold layer is a combination of WW and RWW, while the deep layer is AW. While this thermal structure is to be expected, of note is the fact that warmest part of the surface layer resides over the continental slope, not the shelf. The isopycnals generally slope downward progressing offshore, although they tend to flatten out at the seaward end 


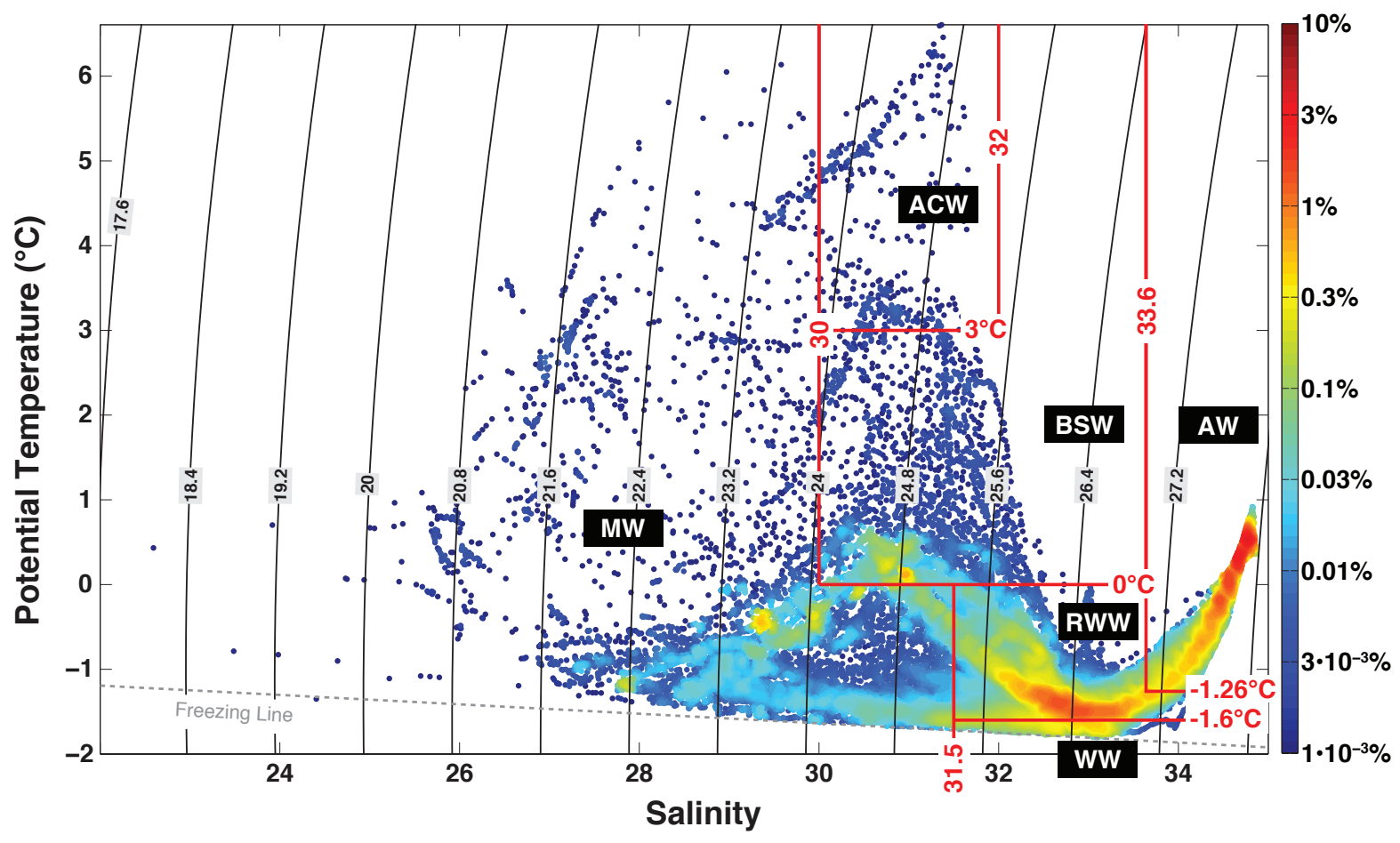

Figure 3: Temperature-Salinity diagram of all of the hydrographic data offshore of the $90 \mathrm{~m}$ isobath and above $300 \mathrm{~m}$ depth. Each point denotes a single measurement, and the color represents the percentage of data within each grid cell of $0.1^{\circ} \mathrm{C}$ temperature by 0.1 salinity. The red lines indicate the different water mass boundaries. $\mathrm{ACW}=$ Alaskan coastal water; $\mathrm{BSW}=$ Bering summer water; $\mathrm{WW}=$ newly-ventilated Pacific winter water; RWW = remnant Pacific winter water; $\mathrm{MW}=$ meltwater; $\mathrm{AW}=$ Atlantic water. 
of the section. There is also a region of enhanced isopycnal slope over the upper continental slope in the AW.

The mean section of absolute geostrophic velocity (Fig. 4b) reveals two distinct circulation components. The first is a bottom-intensified, eastward-flowing shelfbreak jet. While previous studies have suggested the existence of this current using synoptic data (e.g. Pickart et al., 2005; Mathis et al., 2007), our mean section robustly documents that such a feature exists along the edge of the Chukchi Sea. Dynamically this makes sense, as there is northward flow of Pacific water along the eastern flank of Herald Canyon (Woodgate et al., 2005, Pickart et al., 2010) some of which should turn eastward, following isobaths, to form a shelfbreak jet. This is analogous to the formation of the Beaufort shelfbreak jet via the outflow from Barrow Canyon (Pickart et al., 2005). A notable feature of the shelfbreak jet in Fig. $4 \mathrm{~b}$ is the enhanced near-bottom flow of AW associated with the strong isopycnal tilt noted above. Interestingly, the Beaufort shelfbreak jet also has a deep tail of eastward-flowing AW (Nikolopoulos et al., 2009; Brugler et al., 2014), which is believed to be associated with the spin-down phase of upwelling events that are common throughout the year (see Pickart et al., 2011). Further investigation is necessary to determine if the same mechanism is at work on the Chukchi slope.

While the existence of an eastward-flowing shelfbreak jet was anticipated, it was less clear what to expect on the continental slope. Our mean velocity section reveals the presence of a surface-intensified westward current seaward of the shelfbreak that is $\mathrm{O}(50 \mathrm{~km})$ wide (Fig. 4b), significantly broader than the shelfbreak jet. The strongest velocities are in the upper $150 \mathrm{~m}$ (i.e. in the Pacific layer), although the current extends a fair bit deeper than this into the Atlantic layer. Laterally, the strongest mean flow is within $25 \mathrm{~km}$ of the shelfbreak, although there is significant flow out to $60 \mathrm{~km}$ (the mean section suggests a double core structure, but this is due to the relatively small sample size as the synoptic realizations generally do not indicate such a feature).

We refer to this current as the Chukchi slope current. To our knowledge this is the first robust documentation of the current, which we believe emanates (at least in part) from the outflow from Barrow Canyon. As noted in the introduction, the synoptic measurements 


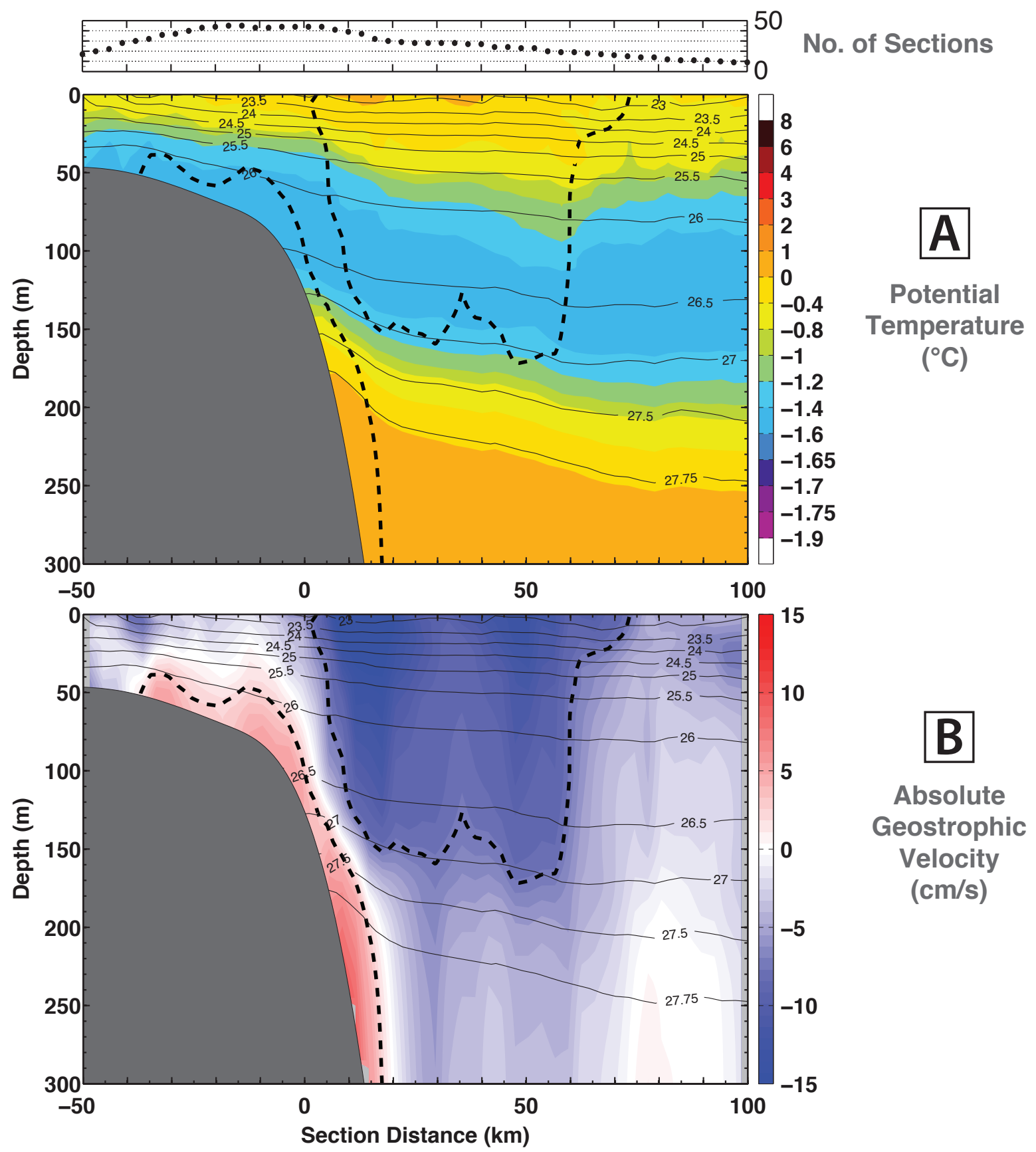

Figure 4: Mean vertical sections constructed from the 46 shipboard transects. (a) Potential temperature, and (b) Absolute geostrophic velocity overlain by potential density (contours, $\mathrm{kg} \mathrm{m}^{-3}$ ). The black dashed lines denote the $5 \mathrm{~cm} / \mathrm{s}$ velocity anomaly contour outlining the shelfbreak jet and slope current (see text). Positive velocities are eastward (the viewer is looking westward). The number of sections contributing to the mean at each cross-slope location is plotted in the top panel. 
reported in Brugler et al. (2014) are consistent with this notion, as are the sea surface temperature data and water column velocity measurements reported by Okkonen et al. (2009). Notably, the largest signature of Pacific summer water in the mean section of Fig. 4 a occurs within the current. The mass budget constructed below (Section 7) also suggests that the Chukchi slope current is fed by outflow from Barrow Canyon. Seaward of the slope current, near the offshore end of the mean section, there is another region of surfaceintensified westward flow. This is weaker and less baroclinic, and is presumed to be the southward edge of the Beaufort Gyre. Such an interpretation is in line with unpublished data from the Beaufort Sea, which indicates that the edge of the gyre is roughly $100 \mathrm{~km}$ offshore of the shelfbreak. This is considered below in more detail in the Discussion section.

The distribution of water masses associated with the mean hydrographic sections supports our claim that the Chukchi slope current advects Pacific water out of Barrow Canyon. In particular, we computed the percent occurrence across the shelf/slope of each of the water masses present in the $\mathrm{T} / \mathrm{S}$ diagram of Fig. 3. These are shown in the different panels of Fig. 5. (Note that there is a steady decrease in occurrence near the seaward edge of the section due to data coverage, but this has been accounted for by normalizing by the number of realizations available at each given location.) MW is present across the entire section in the surface layer, though most prevalent on the outer shelf, while AW is found across the entire section in the deep layer. Notably, the highest percentages of BSW, ACW, and RWW are found within the slope current. By contrast, the largest amount of WW occurs within the shelfbreak jet. These results suggest that the slope current is a fast-track for advecting Pacific water out of Barrow Canyon (in the warm months this would consist of RWW, BSW, and $\mathrm{ACW}$ ), while the shelfbreak jet is a slower, longer route for Pacific water emanating from Herald Canyon (hence WW is only showing up along the Chukchi shelfbreak at this time of year).

\subsection{Transport}

Based on the average absolute geostrophic velocity section (Fig. 4b), the mean westward volume transport of Pacific water in the Chukchi slope current, for the months of July- 

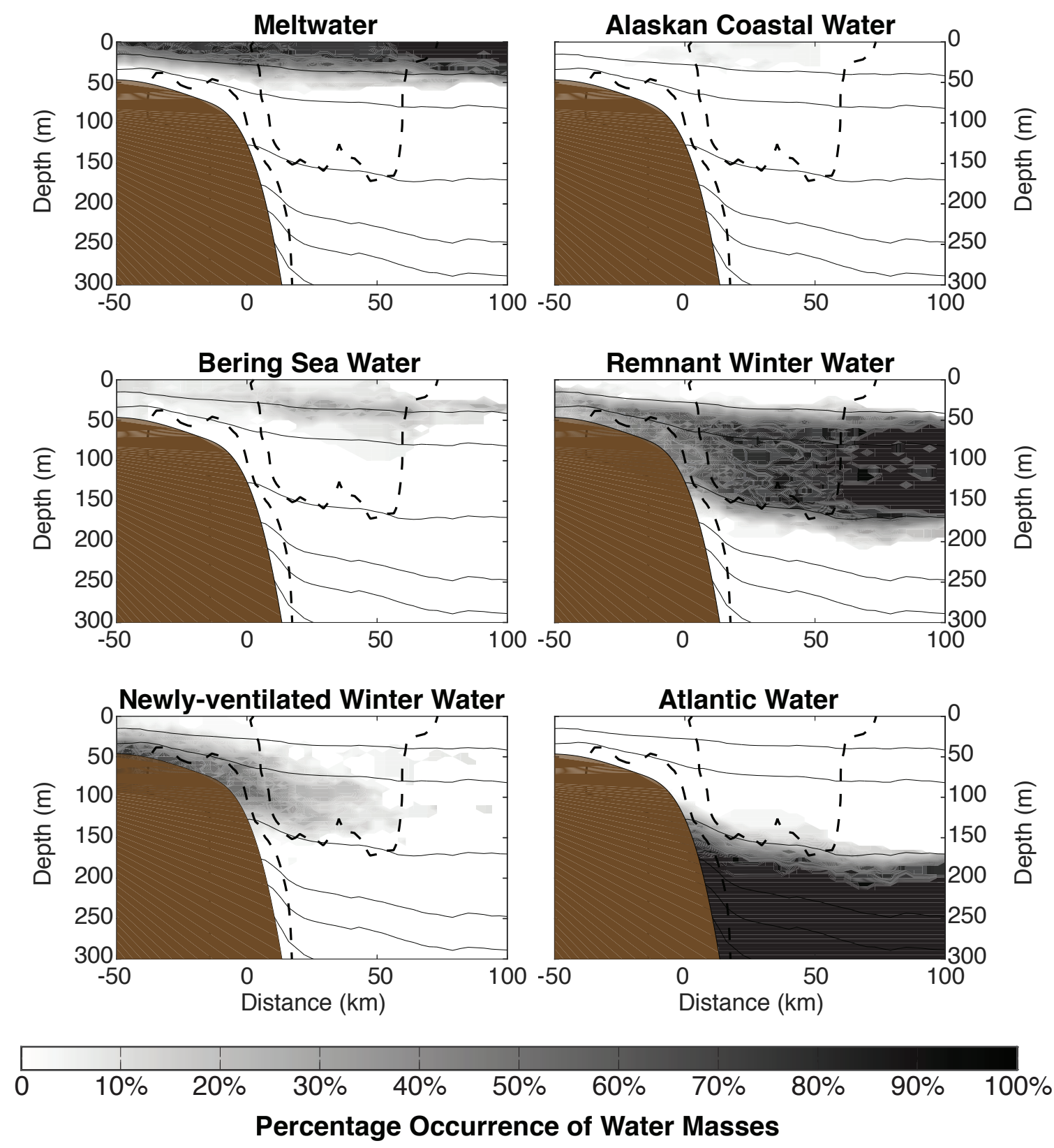

Figure 5: Relative occurrence of the different water masses in the mean hydrographic section. The black dashed lines denote the outline the shelfbreak jet and slope current as in Fig. 4 . 
October, is $-0.50 \pm 0.07 \mathrm{~Sv}$ (all error estimates in the paper are standard errors). This excludes meltwater (see Section 3.3 for how we distinguished between Pacific water and Atlantic water). The corresponding eastward transport of the shelfbreak jet is much smaller than this, $0.10 \pm 0.03 \mathrm{~Sv}$. These values are put into context of the mass budget of the Chukchi shelf in Section 7. The mean heat flux of the Pacific water in the slope current is -1.4 TW, which is roughly half of the summertime estimate of Brugler et al. (2014) for the Beaufort shelfbreak jet (approximately 3 TW). The mean Pacific freshwater transport of the slope current is $-33 \mathrm{mSv}$, which is roughly $50 \%$ greater than the summertime value of the Beaufort shelfbreak jet (approximately $20 \mathrm{mSv}$ ). Both the corresponding heat and freshwater transports of the Chukchi shelfbreak jet are far smaller than these values $(0.18$ TW and $5.3 \mathrm{mSv}$, respectively).

The volume, heat, and freshwater transports of the Chukchi slope current are broken down by water masses in Fig. 6. For this calculation we computed the transports for each realization that measured the slope current and then computed the mean, in order to circumvent the smoothing out of individual water masses in the mean section. (Note that this results in a $2 \%$ increase in volume flux, $22 \%$ increase in heat flux, and $3 \%$ increase in freshwater flux because of the selective sampling.) The largest volume transport component is associated with the RWW, followed by the MW contribution. The other components are comparable with the exception of the ACW, which is quite small. As is true for the volume flux, the heat flux is dominated by RWW and MW. However, the two Pacific summer waters (particularly BSW) have fractionally greater contributions due to their warm temperatures, as does the AW. Finally, the same two water masses dominate the freshwater flux of the slope current - RWW and MW — but the latter contribution is greater due to its lower salinity.

It is worth noting that AW contributes to the full volume transport and heat transport of the slope current by roughly the same amount as BSW (roughly $10 \%$ and $16 \%$ for volume transport and heat transport, respectively; Fig 6 a,b). The fact that AW is flowing westward on the Chukchi slope is curious - this is the opposite direction of the circumpolar boundary current that transports this water mass cyclonically around the sub-basins of the Arctic 

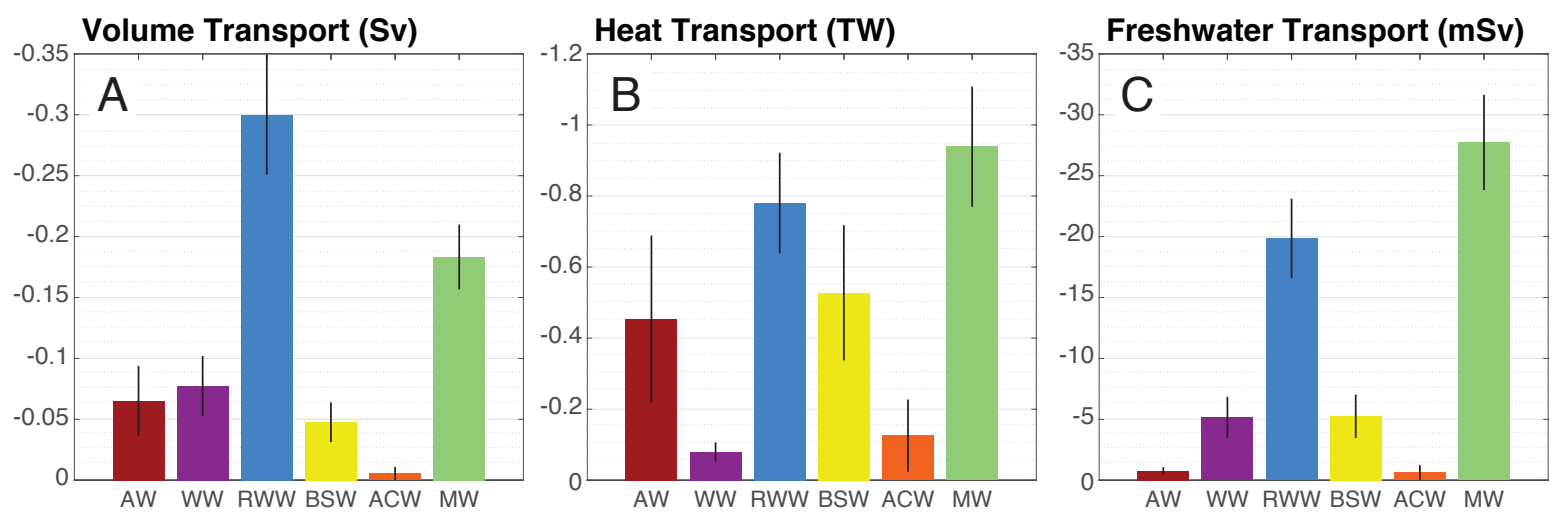

Figure 6: Transport of the Chukchi slope current broken down by water mass (see Fig. 3 for the water masses). Standard errors are indicated by the lines. (a) Volume transport; (b) Heat transport; (c) Freshwater transport.

Ocean (e.g. Rudels et al., 1994; Aksenov et al., 2011). We have no explanation for this, and it warrants further investigation (beyond the scope of the present study).

\section{Variability}

\subsection{Seasonality}

There are pronounced seasonal changes in the presence of the different water masses on the Chukchi slope, as well as variations in the fluxes of mass, heat, and freshwater, from July to October. Starting with the water masses, we quantified the percent occurrence of each water type for each month seaward of the $90 \mathrm{~m}$ isobath (Fig. 7). Both of the Pacific summer waters, BSW and ACW, were barely present (or completely absent) in July and August, but increased in abundance in September. This trend continued for the BSW in October, but the ACW content dropped again that month. von Appen and Pickart (2012) noted that BSW also remained on the Beaufort slope later in the warm season than ACW. The Pacific winter waters, RWW and WW, varied out of phase with each other on the Chukchi slope, with RWW increasing in October and WW decreasing markedly at that time. This is not surprising, since heating/mixing through the summer transforms WW into RWW. Finally, the AW content remained steady from July-September and then increased in October, while the amount of MW decreased steadily through the four-month period. 


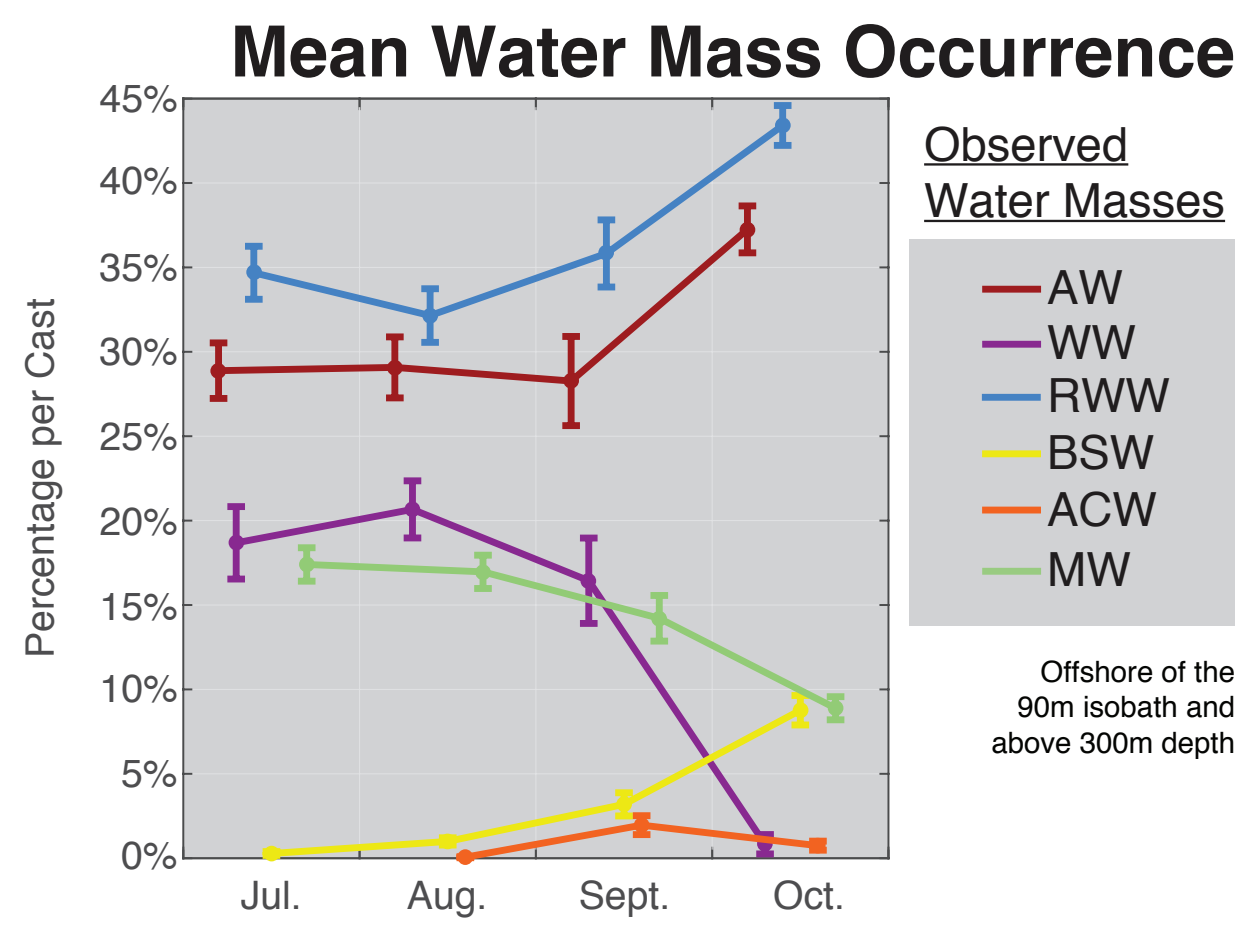

Figure 7: Mean monthly occurrence of water masses on the Chukchi slope offshore of the $90 \mathrm{~m}$ isobath and shallower than $300 \mathrm{~m}$. Standard errors are indicated. (See Fig. 3 for the water masses.) 

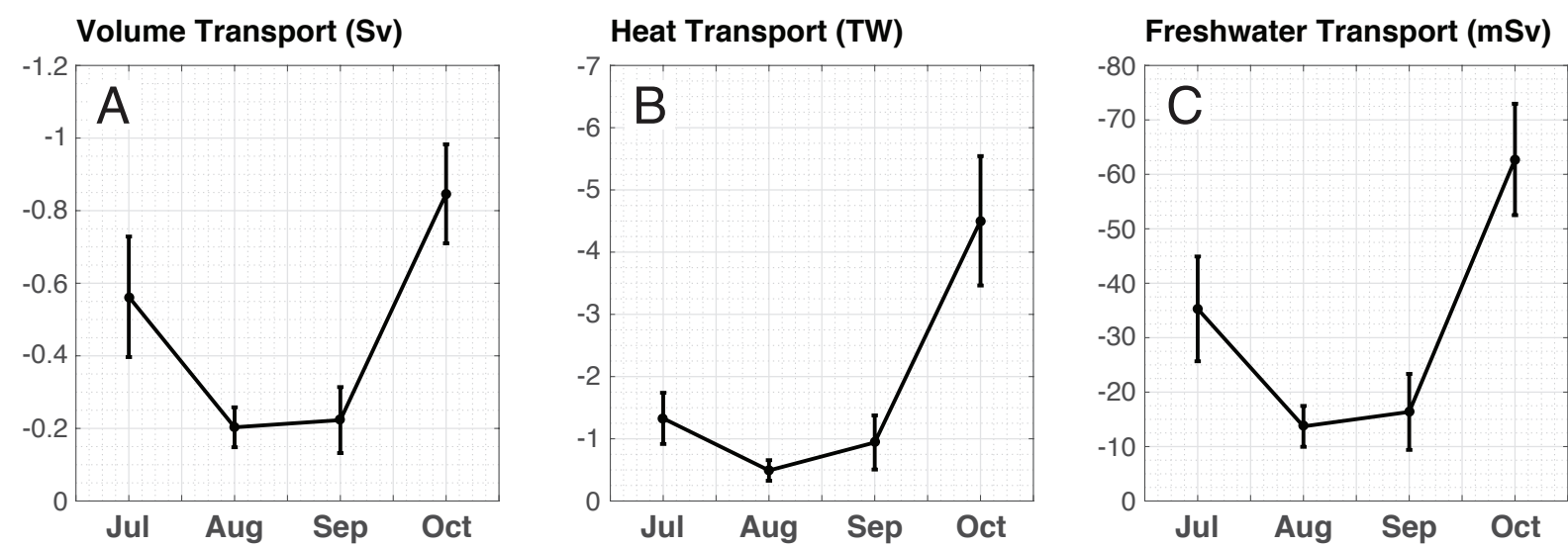

Figure 8: Mean monthly Pacific water transport of the Chukchi slope current with standard errors; $\mathrm{N}=11$ for July, 10 for August, 5 for September, and 8 for October. (a) Volume transport; (b) Heat transport; (c) Freshwater transport.

The most conspicuous seasonal change in Pacific water volume flux of the Chukchi slope current is the increase in westward transport in October (Fig. 8). A possible explanation for this is the seasonality of the winds. We computed the monthly climatological alongshelfbreak 10-m wind speed over the Chukchi slope for the period 2002-14. October has the strongest easterly winds during any month of the year, which would enhance the westward flow of the slope jet. A similar increase in heat flux and freshwater flux occurs during October as well. This is related not only to the wind, but is due in part to a substantial increase in the heat content and freshwater content of the water column (not shown). We note that the freshwater increase in October is not in line with the meltwater percentage (which is a minimum that month, Fig. 7); it is related instead to the increase in the percentage of the RWW and the relatively fresh BSW (note in Fig. 3 that most of the BSW is on the fresh end of that water mass range). In contrast to the Chukchi slope current, there is no pronounced seasonal variation in volume flux and freshwater flux of the Chukchi shelfbreak jet. While the shelfbreak jet reverses direction from eastward to westward in October — likely due to the increased easterly winds that month — the change is not statistically significant. 


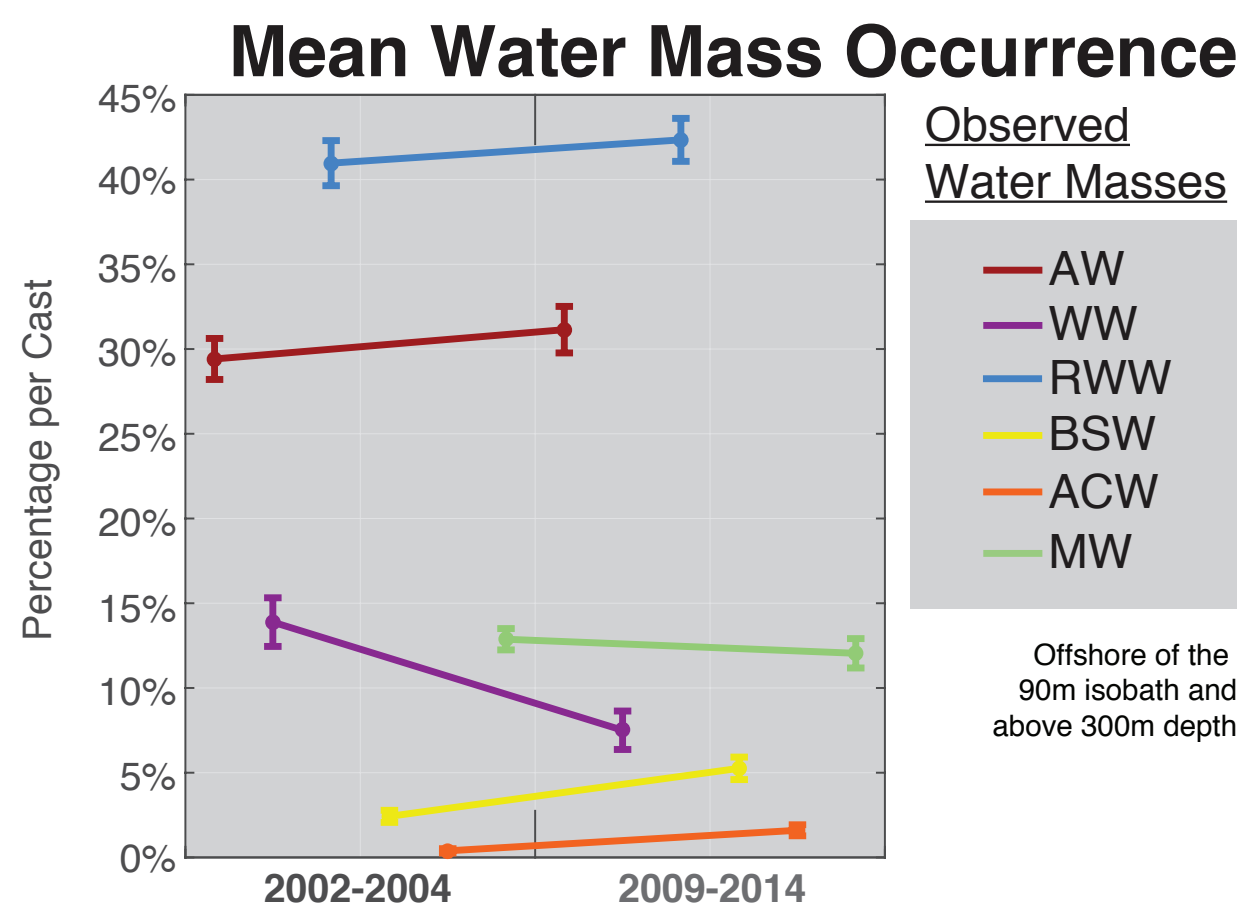

Figure 9: Interannual change in occurrence of water masses on the Chukchi slope from the early regime to the recent regime, offshore of the $90 \mathrm{~m}$ isobath and shallower than $300 \mathrm{~m}$. Standard errors are indicated. (See Fig. 3 for the water masses.)

\subsection{Interannual variability}

As noted in Section 2.1, the temporal coverage of shipboard sections is such that we can only contrast the early regime (2002-4) versus the recent regime (2009-14) for July through October. In addition, to avoid aliasing spatial trends into interannual variability, we have restricted the spatial extent for interannual analyses to be within $300 \mathrm{~km}$ of Barrow Canyon. In terms of the water masses on the slope, there was no significant change in the three most prevalent water masses, the RWW, AW, and MW (Fig. 9). However, the percent contribution of all of the other water masses did change significantly. Both of the Pacific summer waters increased in occurrence, particularly the BSW, while the WW contribution decreased.

The volume, heat, and freshwater transport of Pacific water in the Chukchi slope current all increased significantly from the early regime to the recent regime (Fig. 10). As was 

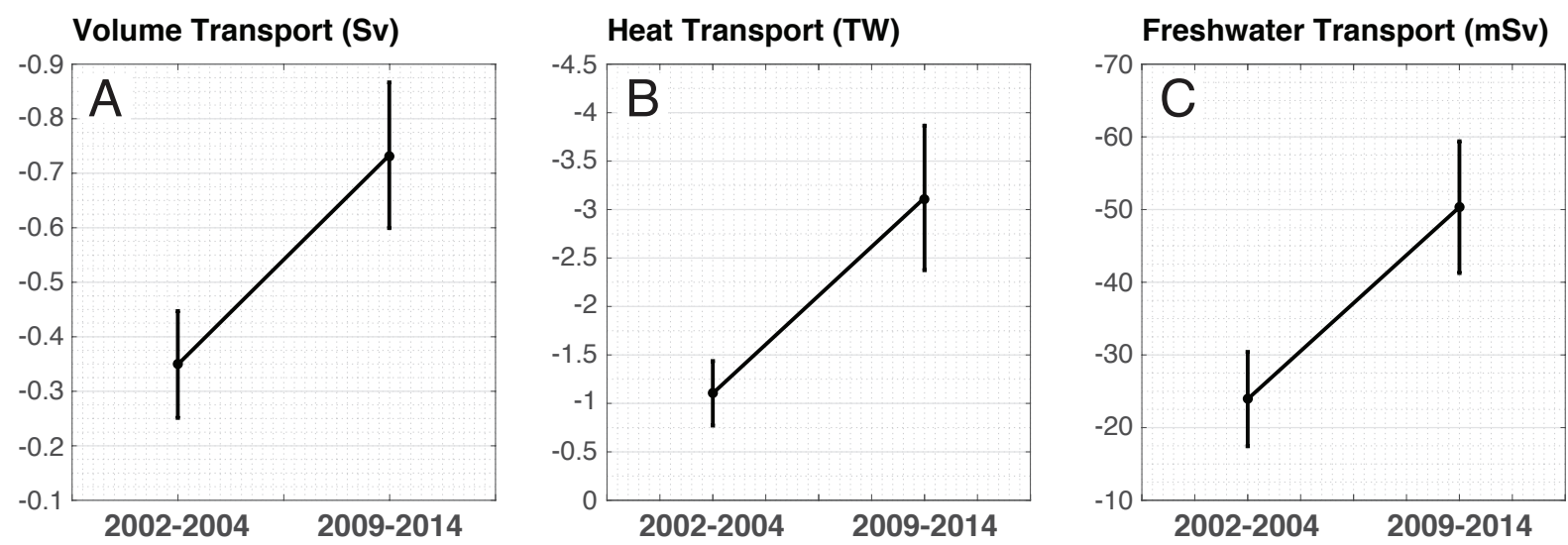

Figure 10: Interannual change in Pacific water transport of the Chukchi slope current from the early regime to the recent regime, with standard errors; $\mathrm{N}=18$ for the early regime, and 16 for the recent regime. (a) Volume transport; (b) Heat transport; (c) Freshwater transport.

the case with the seasonal changes in the fluxes of the current, it seems likely that this was the result of the wind. We calculated the mean along-shelfbreak 10-m wind speed for July-October for each year that we have data. This reveals a noticeable change between the two regimes (Fig. 11). In the early regime, two out of the three years had very weak average winds during this four-month period. By contrast, in the recent regime five out of the six years were characterized by easterly winds. This would favor a stronger westward-flowing slope current in the latter period. This is consistent the results of Brugler et al. (2014), who demonstrated that the eastward-flowing Beaufort shelfbreak jet was retarded by the enhanced easterly winds along the north slope of Alaska over a similar time period. It is also in line with the observed increase in the presence of ACW and BSW on the Chukchi slope during the later regime (Fig. 9). (Our data indicate a decreased transport of the Chukchi shelfbreak jet from the early regime to the later regime, but the change is not statistically meaningful.) 


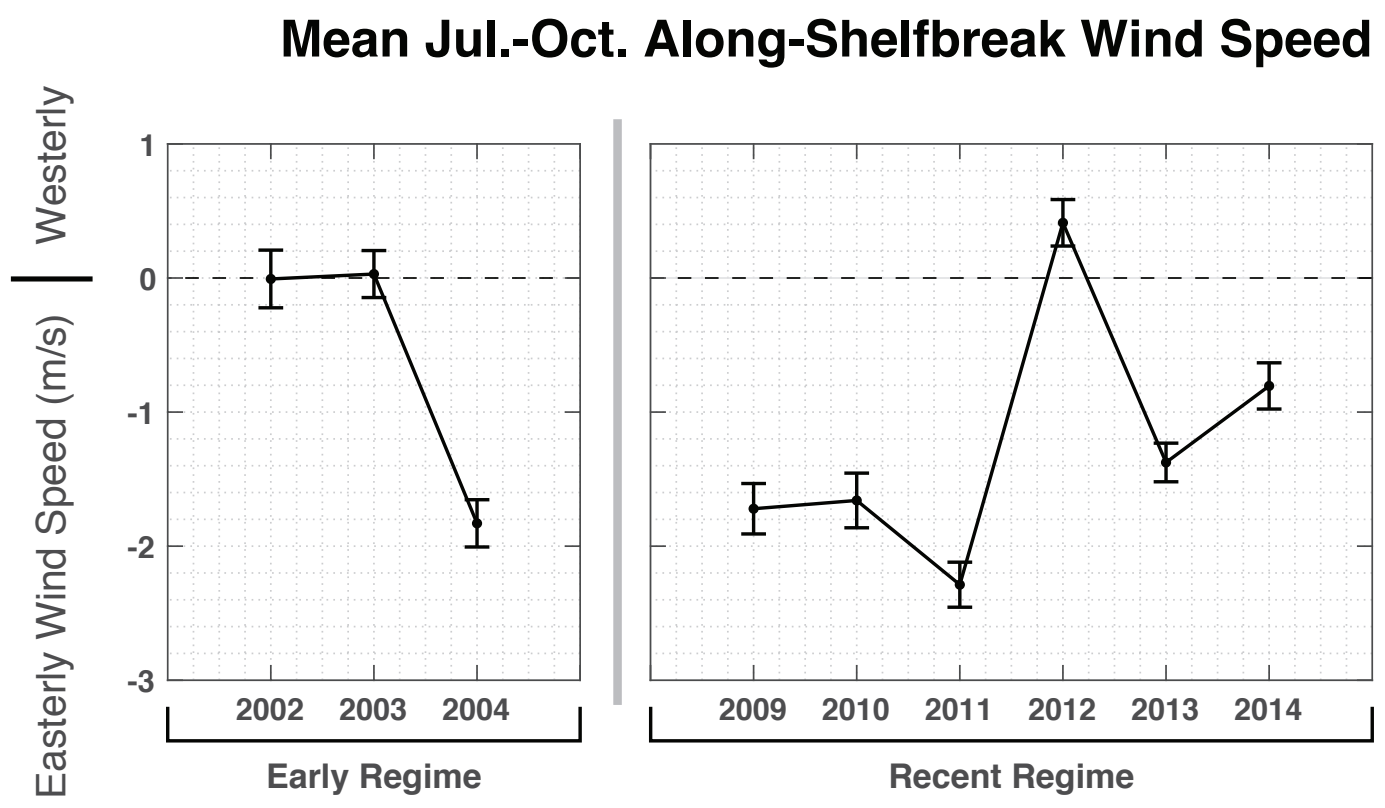

Figure 11: Mean along-shelfbreak 10-m wind speed from July-August each year, averaged over the Chukchi slope region $\left(155-162^{\circ} \mathrm{W}\right.$ and $\left.72-74^{\circ} \mathrm{N}\right)$. The standard errors are indicated. Negative wind speeds are easterly. 


\section{Nature of the Chukchi slope current}

\subsection{Wind influence}

The apparent sensitivity of the Chukchi slope current to easterly winds on seasonal to interannual timescales makes one wonder if the current is present only during periods of substantial winds. For instance, it might be akin to the Beaufort shelfbreak jet, which only flows to the west during upwelling-favorable winds. To investigate this, for each of the synoptic realizations we compared the transport of the current with the strength of the along-shelfbreak 10-m wind speed during/prior to the occupation of the transect (see Section 2.2). This reveals that, while the slope current is enhanced under synoptic wind forcing, it also exists when the winds are weak or even westerly. This relationship is significant at the $90 \%$ confidence interval, and reveals a wind-dependent trend of $-0.04 \mathrm{~Sv}$ per m/s of easterly wind speed with a no-wind volume transport of $-0.45 \mathrm{~Sv}$.

The influence of the wind on the Chukchi slope current is nicely visualized by constructing composite mean vertical sections under calm conditions versus times when there are moderate-to-strong easterly winds (Fig. 12). In the weak wind composite the slope current is clearly evident, but it is relatively weak and the largest velocities are confined to the upper $40 \mathrm{~m}$. By contrast, in the strong easterly wind composite the current is substantially stronger and the large velocities extend to $125 \mathrm{~m}$. One also sees that the shelfbreak jet is considerably weakened under these latter conditions (the shelfbreak jet is reversed to the west in some of the synoptic easterly wind realizations). The overall conclusion is that, while the Chukchi slope current is sensitive to wind forcing, it still transports a notable amount of Pacific water to the west regardless of the synoptic winds.

\subsection{Path and downstream evolution}

Additional questions regarding the slope current are: What is the path of the current? How does it evolve going downstream? What is its ultimate fate? While definitive answers to these questions will require further observations and modeling, we can address some aspects here with the data in hand. As noted above, 37 of the 46 transects measured the presence of the slope current, and these realizations are depicted on a lateral map in Fig. 13 a. In the 


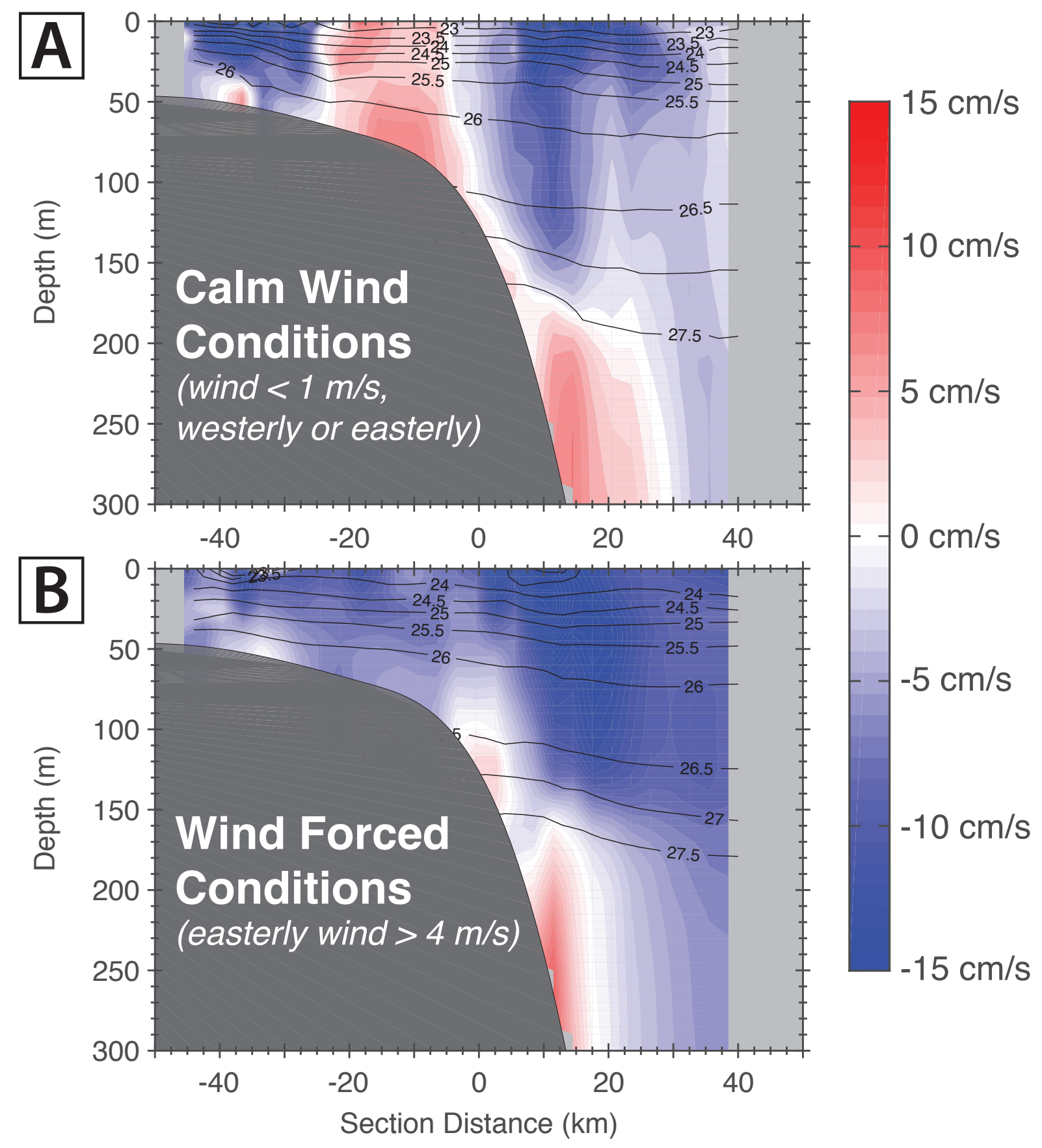

Figure 12: Composite vertical sections of absolute geostrophic velocity (color) and potential density (contours, $\mathrm{kg} \mathrm{m}^{-3}$ ) during (a) calm wind conditions; and (b) times when the easterly winds exceeded $4 \mathrm{~m} / \mathrm{s}$ prior to and during the occupation of the transect. 
figure, the width of the arrows indicates the lateral scale of the current for the realization in question, while the length of the arrows denotes the mean speed of the current averaged over its width and depth (keep in mind that these are not true vectors; they are constrained to be normal to the sections).

One sees that the current is consistently located over the Chukchi continental slope throughout the entire domain, a distance of approximately $500 \mathrm{~km}$ westward from the mouth of Barrow Canyon. The median isobath over which the current resides (i.e. the region of strongest flow) is $238 \mathrm{~m}$. In all but two of the realizations the current was shoreward of the $800 \mathrm{~m}$ isobath, and in $70 \%$ of the realizations it was inshore of the $400 \mathrm{~m}$ isobath. This implies that the current mainly resides on the upper continental slope but is not trapped to a particular isobath; it is instead more reminiscent of a free jet. In addition, we do not observe a statistically significant alongstream trend in transport for either the early regime or the recent regime. In Fig. 13b we also show the analogous lateral map for the shelfbreak jet. It is evident that the shelfbreak jet is weaker and more narrow than the slope current, and at times it reverses to the west (in response to easterly winds, as noted earlier). The shelfbreak jet also does not exhibit any alongstream trend in volume transport.

The notion that the slope current is a meandering free jet suggests that it is baroclinically unstable. This was assessed by computing the Ertel potential vorticity (П) for each section,

$$
\Pi=\underbrace{\frac{-f}{\rho} \frac{\partial \rho}{\partial z}}_{1}+\underbrace{\frac{1}{\rho} \frac{\partial U_{g}}{\partial y} \frac{\partial \rho}{\partial z}}_{2}-\underbrace{\frac{1}{\rho} \frac{\partial U_{g}}{\partial z} \frac{\partial \rho}{\partial y}}_{3}
$$

where $f$ is the Coriolis parameter, $\rho$ is density, and $U_{g}$ is the cross-track absolute geostrophic velocity (see Pickart et al., 2005). Term 1 is the stretching vorticity, term 2 is the relative vorticity, and term 3 is the tilting vorticity. In general, the relative vorticity of the slope current is small (roughly 10-15\% of $f$ ) and the tilting component is negligible. As such, $\Pi$ is dominated by the stretching term. A necessary condition for baroclinic instability is that the cross-stream gradient of $\Pi$ change sign within the current. This was evaluated two ways. First we computed an average vertical profile of $\partial \Pi / \partial y$ for each section and took the mean of this. Then we calculated $\partial \Pi / \partial y$ from the mean vertical sections of Section 4 and 

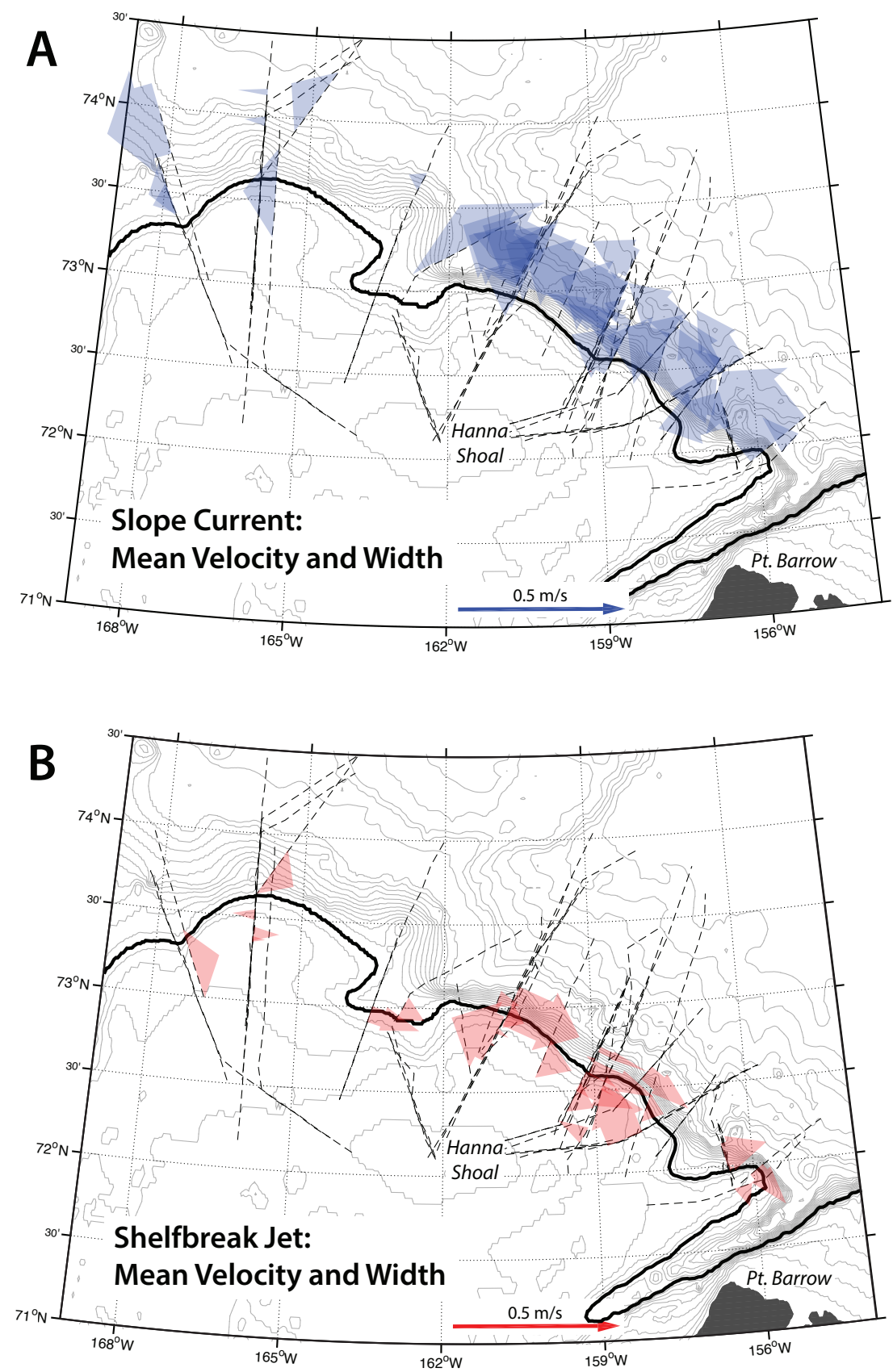

Figure 13: (a) Map showing the position and strength of the Chukchi slope current for each of the transects that measured the current. The width of the arrows denotes the lateral scale of the current, and the length of the arrows denotes the mean speed of the current averaged over its width and depth. The shipboard transects are indicated by the dashed lines. (b) Same as (a) except for the Chukchi shelfbreak jet. 
computed an average vertical profile. Both techniques indicated that from roughly 30-50 $\mathrm{m}$ depth the cross-stream gradient of $\Pi$ was negative, compared to everywhere else in the water column where it was positive. Hence the necessary condition for baroclinic instability is satisfied.

\section{Pacific water mass budget of the Chukchi shelf}

The idea that a significant amount of Pacific-origin water exits Barrow Canyon as a westward-flowing current over the Chukchi slope motivates us to attempt a mass budget where we account for the different inflows and outflows associated with the Chukchi shelf. In this balance, it is assumed that there is no significant mass loss across the Chukchi shelfbreak between Herald and Barrow Canyons. While Timmermans et al. (2014) argue that subduction of Pacific water occurs from the shelf to the basin, our results imply that any associated volume transport would get entrained into the eastward-flowing shelfbreak jet or westward-flowing slope current. Since there is no significant alongstream trend in the volume flux of the shelfbreak jet, and the Pacific water transport of the slope current remains constant as it flows westward from Barrow Canyon, this suggests that cross-shelfbreak subduction of mass is minimal.

An updated version of the Chukchi Sea circulation diagram shown by Brugler et al. (2014) is displayed in Fig. 1, based on the new information presented in this study. In particular, it depicts Pacific water leaving Barrow Canyon in the slope current, as well as Pacific water flowing towards Barrow Canyon in the shelfbreak jet (where it is assumed to enter the western side of the canyon, then recirculate and exit the canyon). Using the known entrances and exits of Pacific water, a mass budget for the Chukchi shelf can be written as follows:

$$
\begin{aligned}
0= & {[\text { Bering Strait Inflow }]-[\text { Barrow Canyon Outflow }] } \\
& -[\text { Long Strait Outflow }]-[\text { Herald Canyon Outflow }] \\
\text { Barrow Canyon Outflow }= & {[\text { Beaufort Shelfbreak Jet }]+[\text { Chukchi Slope Current }] } \\
& -[\text { Chukchi Shelfbreak Jet }]
\end{aligned}
$$


Herald Canyon Outflow $=$ [Chukchi Shelfbreak Jet $]+[$ HCwest $]$

As a simplification, we assume that any mass loss directly north into the basin from Barrow Canyon or Herald Canyon is minimal. The idea here is that such a flux should occur via turbulent processes (e.g. eddy formation as depicted in Fig. 1), which is sporadic. We assume instead that the main transport occurs via well-defined currents. For Herald Canyon it is unknown if a portion of the outflow veers to the west (akin the Chukchi slope current), so we include an unknown contribution from such a current which is referred to in Eq. 4 as HCwest. The mean transport in the Beaufort shelfbreak jet is taken from Nikolopoulos et al. (2009), and the mean transports through Bering Strait and Long Strait are taken from Woodgate et al. (2005). The other two transport values - the Chukchi slope current and Chukchi shelfbreak jet - come from the present study.

The magnitudes of the known terms in Eq. 4 are shown graphically in Fig. 14. One sees that the residual is very small, implying that mass is balanced on the Chukchi shelf within the accuracy of the different transport estimates. It further suggests that the outflow from Herald Canyon is small and that most/all of it feeds the Chukchi shelfbreak jet (i.e. HCwest is essentially zero). This seems to be at odds with the results of Woodgate et al. (2005) who presented a year-long transport value in Herald Canyon of 0.2-0.3 Sv, based mainly on a mooring on the eastern side of the canyon. However, the mooring in question was situated at the head of the canyon, and Pickart et al. (2010) present evidence, both from observations and numerical modeling, that most of the inflow on the eastern side of the canyon gets diverted to the east on the Chukchi shelf just north of Herald Shoal. This water then joins the Central Channel pathway and flows into Barrow Canyon Pickart et al. 2016, see Fig. 11. In addition, data from multiple cruises suggest that there is no outflow from the western side of the mouth of Herald Canyon (Pickart et al., 2010; Linders et al., submitted).

Recently it has been argued that the transport of Pacific water through Bering Strait has increased over the past decade to $1.1 \mathrm{~Sv}$ (Woodgate et al., 2012). The interannual increase in transport of the Chukchi slope current, discussed in Section 5.2, could account for most 


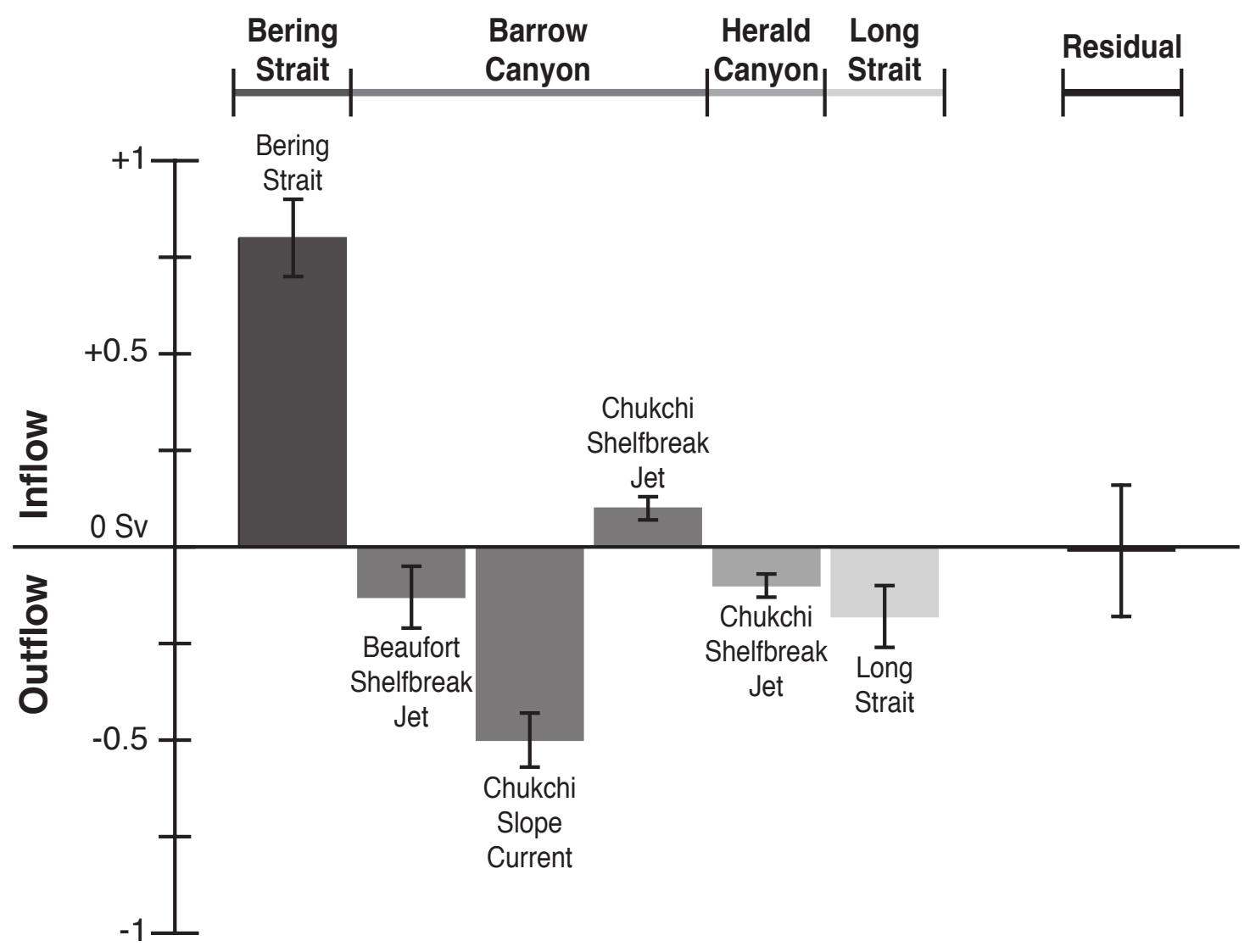

Figure 14: Mass budget of the Chukchi shelf inflows and outflows as discussed in the text, including the residual. Positive transports are inflows and negative transports are outflows. Standard errors are indicated.

of this increase. However, some of the enhancement of the slope current could also be due to diversion of Pacific water away from the Beaufort shelfbreak jet due to the stronger easterly winds of late (Brugler et al., 2014). The balance in Fig. 14 implies that the mean outflow from Barrow Canyon is $0.53 \pm 0.11 \mathrm{~Sv}$. Using 9 years of mooring data from the mouth of Barrow Canyon, Itoh et al. (2013) calculate a mean transport of $0.45 \pm 0.07 \mathrm{~Sv}$. The two values agree with each other within the error bars, although it should be kept in mind that the former estimate does not include the cold season for the Chukchi slope current and Chukchi shelfbreak jet portions.

Despite the uncertainty in the transport estimates of Fig. 14, and keeping in mind 
the disparity in measurement techniques and spatial and temporal coverage of the different studies, the small residual nonetheless suggests that we have accurately accounted for most of the transport of Pacific water onto and off of the Chukchi shelf.

\section{Summary and Discussion}

The analysis presented here has elucidated our understanding of the water masses and circulation along the shelfbreak and continental slope of the Chukchi Sea. The collection of historical shipboard transects confirmed the existence of a shelfbreak jet during the warm season that, in the mean, flows to the east as a bottom-intensified current. The jet is weakened under easterly wind forcing, and, synoptically, it can reverse and flow towards the west. Interestingly, the eastward mean flow extends into the Atlantic layer, associated with strongly sloped isopycnals becoming shallower onshore. Such a deep tail of the shelfbreak jet transporting Atlantic water is also observed in the Beaufort shelfbreak jet, but the mechanism for this in the Chukchi domain remains unexplored.

Offshore of the shelfbreak our data indicated the presence of a current flowing to the west, which we have named the Chukchi slope current. The current is surface-intensified, $\mathrm{O}(50 \mathrm{~km})$ wide, located mainly on the upper continental slope, and extends into the Atlantic layer (although the flow at depth is weak). In the mean (Jul-Oct) it transports $0.50 \pm 0.07$ Sv of Pacific water westward. In October, the Pacific water transport increases likely due to the stronger autumn easterly winds. The transport increased from the early regime (2002-4) to the recent regime (2009-14) presumably due to the enhanced zonal winds over this time frame. There is no alongstream trend in the cross-slope position of the current nor in the volume flux of the current. However, the current appears to meander, which implies that it is hydrodynamically unstable. Indeed, the cross-stream gradient of the Ertel potential vorticity changes sign with depth, which satisfies the necessary condition for baroclinic instability.

We believe that the slope current emanates from Barrow Canyon. This is consistent with the fact that the highest concentrations of the Pacific summer waters and remnant Pacific winter water were found in the current (the highest concentrations of newly ventilated Pacific winter water were observed in the shelfbreak jet, which is expected based on the seasonal 
timing of water exiting the Chukchi shelf). Furthermore, taking into account the transport of the Chukchi slope current and the Chukchi shelfbreak jet, we were able to construct a balanced mass budget for the different Chukchi shelf inflows and outflows. We note that several recent studies present schematic representations of the regional circulation that indicate flow emanating from Barrow Canyon and turning westward (e.g. Day et al., 2013; Dunton et al., 2014; Wood et al., 2015; Moore et al., 2016). However, none of these studies invoke data to support this notion.

It remains to be determined why such a large portion of the Pacific water exiting Barrow Canyon turns to the left instead of the right. Pickart et al. (2005) observed that newly ventilated Pacific winter water flowing northward through Barrow Canyon transposed from the western side of the canyon to the eastern side, suggesting that most of the flow should progress eastward in the Beaufort shelfbreak jet. However, this was a synoptic survey which may not be representative of the mean, or it may be that the densest Pacific water does in fact progress eastward out of the canyon. Keep in mind that most of the newly ventilated Pacific winter water in our mean section was found flowing eastward in the Chukchi shelfbreak jet. It also should be stressed that our data were confined to the warm season; the situation could be different during the other months of the year, although the mass balance in Fig. 14 suggests that this is not generally the case.

It also needs to be explored what role the Beaufort Gyre might play in the existence and path of the Chukchi slope current. We have argued here that the slope current is not the southern arm of the gyre. In addition to the above evidence that the slope current originates from Barrow Canyon, it is difficult to believe that the gyre would be situated at such a shallow isobath on the Chukchi slope (the median isobath corresponding to the center of the slope current is $238 \mathrm{~m}$ ). If this were the case, then one would think the same should be true on the Beaufort slope. A mooring array deployed across the Beaufort shelfbreak and slope from $2002-4$ at $152^{\circ} \mathrm{W}$ showed no evidence of this (Nikolopoulos et al., 2009). In particular, the flow is eastward over this part of the continental slope. We note however, that the bathymetry of the Beaufort slope is different than that of the Chukchi Slope, and the presence of the Northwind Ridge could influence the location of the gyre west of Barrow 
Canyon.

On the other hand, it is quite possible that the presence of the Beaufort Gyre is dynamically tied to the existence of the slope current such that the two features are not entirely distinct. For instance, ice velocity maps show westward flow at the outskirts of the Beaufort Gyre near the edge of the Chukchi Sea. This is shown clearly in Steele et al. (2004), who argue that, under negative Arctic Oscillation conditions, the gyre expands towards the Beaufort and Chukchi shelves (although Steele et al. (2004) state that ACW emanates from Barrow Canyon as eddies that subsequently get entrained into the gyre under these conditions). The winter mean sea surface height and surface geostrophic velocity maps of Mizobata et al. (2016) show evidence of a westward flow over the Chukchi slope that at times appears to be a separate current and at other times seems to be part of the gyre (see their Fig. 4). Furthermore, a 10-yr mean model simulation presented by Zhang et al. (2016) shows water exiting Barrow Canyon and turning westward along the southern edge of the Beaufort Gyre. Neither of these studies discuss this aspect of their results.

The role of wind in the formation of the Chukchi slope current needs to be investigated further as well. Okkonen et al. (2009) noted that, when the winds are out of the east, the Alaska coastal current can be displaced to the western side of Barrow Canyon. They also presented a sea surface temperature map during such conditions that showed a plume of warm water extending to the west out of the canyon. This is consistent with Brugler et al. (2014) who showed similar satellite evidence, along with velocity data revealing the beginnings of the slope current. Surface drifters also depict flow heading west out of the canyon in response to wind events (Weingartner et al., 2015). Using a Pacific water tracer in a model simulation, Watanabe and Hasumi (2009) demonstrated that much of the water veers westward from Barrow Canyon during periods of strong easterly winds. It must be remembered, however, that while the Chukchi slope current is enhanced due to wind forcing, it is also present outside of such events, as demonstrated in the present study.

There are numerous ramifications associated with the notion that most of the Pacific water exiting Barrow Canyon progresses westward instead of eastward. Based on our data, the current has the potential to melt approximately $64,000 \mathrm{~km}^{2}$ of $1-\mathrm{m}$ thick ice over the 
period July-October, which is equivalent to a region extending $170 \mathrm{~km}$ seaward from the shelf edge between the mouth of Barrow Canyon and $166^{\circ} \mathrm{W}$. The freshwater transport of the slope current is also substantial and could contribute to the freshwater reservoir of the Beaufort Gyre. The Pacific water needs to be fluxed offshore for this to happen, and it is unknown by what means this might occur, e.g. via eddy formation and/or wind-driven exchange (both of which occur in the Beaufort shelfbreak jet). It also remains to be determined what the ultimate fate of the Chukchi slope current is. Perhaps the current becomes ill-defined farther to the west or becomes entrained into the Beaufort Gyre. Further investigation is necessary to explore these and other aspects of the current, including its role in the regional ecosystem.

\section{Acknowledgments}

We thank Dan Torres and Frank Bahr for the processing and quality control of the ADCP data, Carolina Nobre for help with programming and graphics, and Mike Spall and Tom Weingartner for helpful discussions. This work was funded under contract M12AC00008 from the Bureau of Ocean and Energy Management. The compiled hydrography and velocity data are available through the Woods Hole Open Access Server (http://hdl.handle.net/1912/8170), where we have listed the original publicly-available sources.

\section{References}

Aagaard, K., Carmack, E., 1989. The role of sea ice and other fresh water in the arctic circulation. Journal of Geophysical Research 94, 14485-14498. doi:10.1029/jc094ic10p14485.

Aksenov, Y., Ivanov, V.V., Nurser, A.J.G., Bacon, S., Polyakov, I.V., Coward, A.C., Naveira-Garabato, A.C., Beszczynska-Moeller, A., 2011. The arctic circumpolar boundary current. Journal of Geophysical Research: Oceans 116, C09017. doi:10.1029/2010JC006637.

von Appen, W.J., Pickart, R.S., 2012. Two configurations of the western arctic shelfbreak current in summer. Journal of Physical Oceanography 42, 329-351. doi:10.1175/jpo-d-11-026.1.

Arrigo, K.R., Perovich, D.K., Pickart, R.S., Brown, Z., van Dijken, G., Lowry, K., Mills, M., Palmer, M., Balch, W., Bates, N., Benitez-Nelson, C., Brownlee, E., Frey, K., Laney, S., Mathis, J., Matsuoka, A., Mitchell, B., Moore, G., Reynolds, R., Sosik, H., Swift, J., 2014. Phytoplankton blooms beneath the 
sea ice in the chukchi sea. Deep Sea Research Part II: Topical Studies in Oceanography 105, 1-16. doi $10.1016 / j \cdot d s r 2.2014 .03 .018$

Brugler, E.T., Pickart, R.S., Moore, G., Roberts, S., Weingartner, T.J., Statscewich, H., 2014. Seasonal to interannual variability of the pacific water boundary current in the beaufort sea. Progress in Oceanography 127, 1-20. doi $10.1016 / \mathrm{j} \cdot$ pocean.2014.05.002.

Coachman, L., Aagaard, K., Tripp, R., 1975. Bering Strait: The regional physical oceanography. University of Washington Press.

Day, R.H., Weingartner, T.J., Hopcroft, R.R., Aerts, L.A., Blanchard, A.L., Gall, A.E., Gallaway, B.J., Hannay, D.E., Holladay, B.A., Mathis, J.T., Norcross, B.L., Questel, J.M., Wisdom, S.S., 2013. The offshore northeastern chukchi sea, alaska: A complex high-latitude ecosystem. Continental Shelf Research 67, 147-165. doi:10.1016/j.csr.2013.02.002.

Dunton, K.H., Grebmeier, J.M., Trefry, J.H., 2014. The benthic ecosystem of the northeastern chukchi sea: An overview of its unique biogeochemical and biological characteristics. Deep Sea Research Part II: Topical Studies in Oceanography 102, 1-8. doi:10.1016/j.dsr2.2014.01.001.

Gong, D., Pickart, R.S., 2016. Early summer water mass transformation in the eastern chukchi sea. Deep Sea Research Part II: Topical Studies in Oceanography 130, 43-55. doi:10.1016/j.dsr2.2016.04.015.

Hill, V., Cota, G., Stockwell, D., 2005. Spring and summer phytoplankton communities in the chukchi and eastern beaufort seas. Deep Sea Research Part II: Topical Studies in Oceanography 52, 3369-3385. doi: $10.1016 /$ j.dsr2.2005.10.010.

Itoh, M., Nishino, S., Kawaguchi, Y., Kikuchi, T., 2013. Barrow canyon volume, heat, and freshwater fluxes revealed by long-term mooring observations between 2000 and 2008. Journal of Geophysical Research: Oceans 118, 4363-4379. doi 10.1002/jgrc.20290.

Itoh, M., Shimada, K., Kamoshida, T., McLaughlin, F., Carmack, E., Nishino, S., 2012. Interannual variability of pacific winter water inflow through barrow canyon from 2000 to 2006 . Journal of Oceanography 68, 575-592. doi:10.1007/s10872-012-0120-1

Lin, P., Pickart, R.S., Stafford, K.M., Moore, G.W.K., Torres, D.J., Bahr, F., Hu, J., 2016. Seasonal variation of the beaufort shelfbreak jet and its relationship to arctic cetacean occurrence. Journal of Geophysical Research: Oceans 121, 8434-8454. doi:10.1002/2016JC011890

Linders, J., Pickart, R.S., Björk, G., Moore, G., submitted. On the nature and origin of water masses in herald canyon, chukchi sea: Synoptic surveys in summer 2004, 2008, and 2009. Deep Sea Research Part I: Oceanographic Research Papers .

Llinás, L., Pickart, R.S., Mathis, J.T., Smith, S.L., 2009. Zooplankton inside an arctic ocean cold-core eddy: Probable origin and fate. Deep Sea Research Part II: Topical Studies in Oceanography 56, 1290-1304. doi $10.1016 / j . d s r 2.2008 .10 .020$. 
Lowry, K.E., Pickart, R.S., Mills, M.M., Brown, Z.W., van Dijken, G.L., Bates, N.R., Arrigo, K.R., 2015. The influence of winter water on phytoplankton blooms in the chukchi sea. Deep Sea Research Part II: Topical Studies in Oceanography 118, Part A, 53-72. doi:10.1016/j.dsr2.2015.06.006.

Mathis, J.T., Pickart, R.S., Hansell, D.A., Kadko, D., Bates, N.R., 2007. Eddy transport of organic carbon and nutrients from the chukchi shelf: Impact on the upper halocline of the western arctic ocean. Journal of Geophysical Research: Oceans 112, C05011. doi:10.1029/2006JC003899.

Mesinger, F., DiMego, G., Kalnay, E., Mitchell, K., Shafran, P.C., Ebisuzaki, W., Jovic, D., Woollen, J., Rogers, E., Berbery, E.H., Ek, M.B., Fan, Y., Grumbine, R., Higgins, W., Li, H., Lin, Y., Manikin, G., Parrish, D., Shi, W., 2006. North american regional reanalysis: A long-term, consistent, high-resolution climate dataset for the north american domain, as a major improvement upon the earlier global reanalysis datasets in both resolution and accuracy. Bulletin of the American Meteorological Society 87, 343-360. doi $10.1175 /$ bams-87-3-343.

Mizobata, K., Watanabe, E., Kimura, N., 2016. Wintertime variability of the beaufort gyre in the arctic ocean derived from cryosat-2/siral observations. Journal of Geophysical Research: Oceans 121, 1685-1699. doi $10.1002 / 2015 \mathrm{JC} 011218$

Moore, S.E., Stabeno, P.J., Grebmeier, J.M., Okkonen, S.R., 2016. The arctic marine pulses model: linking annual oceanographic processes to contiguous ecological domains in the pacific arctic. Deep Sea Research Part II: Topical Studies in Oceanography doi $10.1016 / j . d s r 2.2016 .10 .011$.

Muench, R.D., Schumacher, J.D., Salo, S.A., 1988. Winter currents and hydrographic conditions on the northern central bering sea shelf. Journal of Geophysical Research: Oceans 93, 516-526. doi 10.1029/ JC093iC01p00516.

Nikolopoulos, A., Pickart, R.S., Fratantoni, P.S., Shimada, K., Torres, D.J., Jones, E.P., 2009. The western arctic boundary current at $152^{\circ} \mathrm{w}$ : Structure, variability, and transport. Deep Sea Research Part II: Topical Studies in Oceanography 56, 1164-1181. doi $10.1016 / j . d s r 2.2008 .10 .014$.

Okkonen, S.R., Ashjian, C.J., Campbell, R.G., Maslowski, W., Clement-Kinney, J.L., Potter, R., 2009. Intrusion of warm bering/chukchi waters onto the shelf in the western beaufort sea. Journal of Geophysical Research: Oceans 114, C00A11. doi $10.1029 / 2008 \mathrm{JC} 004870$

Pacini, A., Pickart, R., Moore, G., Nobre, C., Bahr, F., Vage, K., Arrigo, K., submitted. Characteristics and transformation of pacific winter water on the chukchi shelf in late spring. Deep Sea Research Part II: Topical Studies in Oceanography .

Pickart, R.S., 2004. Shelfbreak circulation in the alaskan beaufort sea: Mean structure and variability. Journal of Geophysical Research 109, C04024. doi 10.1029/2003jc001912.

Pickart, R.S., Moore, G., Mao, C., Bahr, F., Nobre, C., Weingartner, T.J., 2016. Circulation of winter water on the chukchi shelf in early summer. Deep Sea Research Part II: Topical Studies in Oceanography 130, 
56-75. doi:10.1016/j.dsr2.2016.05.001.

Pickart, R.S., Pratt, L.J., Torres, D.J., Whitledge, T.E., Proshutinsky, A.Y., Aagaard, K., Agnew, T.A., Moore, G., Dail, H.J., 2010. Evolution and dynamics of the flow through herald canyon in the western chukchi sea. Deep Sea Research Part II: Topical Studies in Oceanography 57, 5-26. doi:10.1016/j.dsr2. 2009.08 .002

Pickart, R.S., Schulze, L.M., Moore, G., Charette, M.A., Arrigo, K.R., van Dijken, G., Danielson, S.L., 2013a. Long-term trends of upwelling and impacts on primary productivity in the alaskan beaufort sea. Deep Sea Research Part I: Oceanographic Research Papers 79, 106-121. doi 10.1016/j.dsr.2013.05. 003 .

Pickart, R.S., Spall, M.A., Mathis, J.T., 2013b. Dynamics of upwelling in the alaskan beaufort sea and associated shelfbasin fluxes. Deep Sea Research Part I: Oceanographic Research Papers 76, 35-51. doi:10. $1016 / j \cdot d s r .2013 .01 .007$.

Pickart, R.S., Spall, M.A., Moore, G., Weingartner, T.J., Woodgate, R.A., Aagaard, K., Shimada, K., 2011. Upwelling in the alaskan beaufort sea: Atmospheric forcing and local versus non-local response. Progress in Oceanography 88, 78-100. doi:10.1016/j.pocean.2010.11.005

Pickart, R.S., Weingartner, T., Pratt, L., Zimmermann, S., Torres, D., 2005. Flow of winter-transformed pacific water into the western arctic. Deep Sea Research Part II: Topical Studies in Oceanography 52, 3175-3198. doi:10.1016/j.dsr2.2005.10.009.

Pisareva, M.N., Pickart, R.S., Spall, M., Nobre, C., Torres, D., Moore, G., Whitledge, T.E., 2015. Flow of pacific water in the western chukchi sea: Results from the 2009 rusalca expedition. Deep Sea Research Part I: Oceanographic Research Papers 105, 53-73. doi 10.1016/j.dsr.2015.08.011.

Roach, A., Aagaard, K., Pease, C., Salo, S., Weingartner, T., Pavlov, V., Kulakov, M., 1995. Direct measurements of transport and water properties through the bering strait. Journal of Geophysical Research 100, 18443-18457. doi $10.1029 / 95$ jc01673.

Rudels, B., Jones, E.P., Anderson, L.G., Kattner, G., 1994. On the intermediate depth waters of the arctic ocean, in: Johannessen, O., Muench, R., Overland, J. (Eds.), The Polar Oceans and Their Role in Shaping the Global Environment. American Geophysical Union. volume 85, pp. 33-46. doi 10.1029/GM085p0033.

Schulze, L.M., Pickart, R.S., 2012. Seasonal variation of upwelling in the alaskan beaufort sea: Impact of sea ice cover. Journal of Geophysical Research 117, C06022. doi:10.1029/2012jc007985.

Spall, M.A., 2007. Circulation and water mass transformation in a model of the chukchi sea. Journal of Geophysical Research: Oceans 112, C05025. doi:10.1029/2005JC003364.

Steele, M., Morison, J., Ermold, W., Rigor, I., Ortmeyer, M., Shimada, K., 2004. Circulation of summer pacific halocline water in the arctic ocean. Journal of Geophysical Research: Oceans 109, C02027. doi $10.1029 / 2003$ JC002009. 
Steele, M., Zhang, J., Ermold, W., 2010. Mechanisms of summertime upper arctic ocean warming and the effect on sea ice melt. Journal of Geophysical Research: Oceans 115, C11004. doi:10.1029/2009JC005849.

Timmermans, M.L., Proshutinsky, A., Golubeva, E., Jackson, J.M., Krishfield, R., McCall, M., Platov, G., Toole, J., Williams, W., Kikuchi, T., Nishino, S., 2014. Mechanisms of pacific summer water variability in the arctic's central canada basin. Journal of Geophysical Research: Oceans 119, 7523-7548. doi 10 . 1002/2014JC010273

Watanabe, E., Hasumi, H., 2009. Pacific water transport in the western arctic ocean simulated by an eddyresolving coupled sea ice-ocean model. Journal of Physical Oceanography 39, 2194-2211. doi 10.1175/ 2009JP04010.1.

Weingartner, T.J., Aagaard, K., Woodgate, R.A., Danielson, S., Sasaki, Y., Cavalieri, D., 2005. Circulation on the north central chukchi sea shelf. Deep Sea Research Part II: Topical Studies in Oceanography 52, 3150-3174. doi $10.1016 /$ j.dsr2.2005.10.015.

Weingartner, T.J., Cavalieri, D.J., Aagaard, K., Sasaki, Y., 1998. Circulation, dense water formation, and outflow on the northeast chukchi shelf. Journal of Geophysical Research 103, 7647-7661. doi 10.1029/ 98JC00374.

Weingartner, T.J., Irvine, C., Dobbins, E., Danielson, S., DeSousa, L., Adams, B., Suydam, R., Neatok, W., 2015. Satellite-tracked Drifter Measurements in the Chukchi and Beaufort Seas. Technical Report 2015-022. Bureau of Ocean Energy Management. URL: https://www.boem.gov/BOEM-2015-022/.

Wood, K.R., Bond, N.A., Danielson, S.L., Overland, J.E., Salo, S.A., Stabeno, P.J., Whitefield, J., 2015. A decade of environmental change in the pacific arctic region. Progress in Oceanography 136, 12-31. doi $10.1016 / j$.pocean.2015.05.005.

Woodgate, R.A., Aagaard, K., Weingartner, T.J., 2005. Monthly temperature, salinity, and transport variability of the bering strait through flow. Geophysical Research Letters 32, L04601. doi 10.1029/ 2004GL021880.

Woodgate, R.A., Weingartner, T., Lindsay, R., 2010. The 2007 bering strait oceanic heat flux and anomalous arctic sea-ice retreat. Geophysical Research Letters 37, L01602. doi 10.1029/2009g1041621.

Woodgate, R.A., Weingartner, T.J., Lindsay, R., 2012. Observed increases in bering strait oceanic fluxes from the pacific to the arctic from 2001 to 2011 and their impacts on the arctic ocean water column. Geophysical Research Letters 39, L24603. doi 10.1029/2012g1054092.

Zhang, J., Steele, M., Runciman, K., Dewey, S., Morison, J., Lee, C., Rainville, L., Cole, S., Krishfield, R., Timmermans, M.L., Toole, J., 2016. The beaufort gyre intensification and stabilization: A model-observation synthesis. Journal of Geophysical Research: Oceans 121, 7933-7952. doi $10.1002 / 2016$ JC012196. 